\title{
A Study on the Symbols and Themes of Sandplay Therapy for Children of Myanmar Refugees living in Malaysia
}

\author{
Hyeyoung Kim* \\ Eunjin Cho** \\ Mikyung Jang ${ }^{* * *}$
}

\begin{abstract}
This study categorized and analyzed the themes and symbols that appeared in the sandplay therapy of Myanmar Chin children living as refugees in Malaysia. The researcher provided individual sandplay therapy to five children attending a UN refugee school in Malaysia for four weeks in July 2018. There were five sessions for each child and 50 minutes per session. The researcher used a Kalffian sandplay approach to provide a free and protected space for the children. They used Creswell's (2007) qualitative case study method to understand the themes and symbols and, through a comprehensive analysis of all cases, they found five common themes and symbols. These themes were 'fear/threat and the resistance from the heart to it', 'protection and care', 'the existence of god and guilt feelings', 'the effort to recover normal life', and 'do not give up hope for a normal life'. The refugee children expressed their emotional pain in the sand tray so that the traumas they had experienced while escaping and the chaos in their present lives appeared prominently and repeatedly there. As the sessions progressed, however, they expressed a hope to return to their normal lives as they recovered some sense of stability. They could more easily express their inner pain in sandplay than in language, and project themselves safely and express their emotions. It is a fact that, like all other children, the innate and archetypal healing power of these refugee children's psyche allowed them to respond strongly to sandplay, despite the short-term therapeutic intervention, the horrors of their experiences and the unstable situations they face. Future research should evaluate the effectiveness of a psychotherapeutic approach that considers the social and cultural specificity of refugee children and their various emotional problems and secure economic aid and legal status for them.
\end{abstract}

Keywords : fear and threat, protection and care, God's presence and guilt, recovery of life, hope of a normal life

\footnotetext{
* Main author, Ph.D. Student Child Welfare Department school of, Nam Seoul National University (rla3430@hanmail.net)

** Corresponding author, Student Child Welfare Department school of, Nam Seoul National University (eunjin1805@naver.com)

*** Co-author, Professor, Department of Child Welfare, Namseoul University (jangmiky@hotmail.com)
} 
Journal of Symbols \& Sandplay Therapy, Vol.12 No.1.

\section{I . Introduction}

Refugees are people who flee persecution for reasons of race, religion, nationality, or political opinion and cannot return to their country (Alayarian, 2007). Currently, refugees from Myanmar are flowing into various neighboring countries. The background of the refugee outbreak in Myanmar is quite complex and has a long history. Myanmar is a federal state composed of the majority Burmese, indigenous minorities and foreign minorities that gained independence from the British in January 1948. Since Myanmar declared independence, more than a dozen ethnic minorities on the border have launched armed struggles against government forces, claiming independence from the majority Burmese government. The reason these minorities are demanding autonomy is that they oppose Myanmar's ethnic discrimination policy against them and the resulting repression from the country's Burmese-centered military regime, which has led to a worse situation than in the colonial era. The largest ethnic minority groups in Myanmar include the Rohingya, Shan, Karen, Kachin, and Chin, and Chinese and Indians also make up a significant portion. Traditionally, Myanmar has a Theravada Buddhist culture, but minority groups such as the Karen, Kachin, and Chin have accepted Christianity (Jang, 2012).

The Myanmar government classifies 135 ethnic groups in the country, with dozens of anti-government organizations scattered in proportion to the number, but the number of casualties and refugees still continues to rise as many are engaged in anti-government armed struggles (Jang, 2012). Since 2017, in western Myanmar, the government has begun ethnic cleansing of the Rohingya in order to subdue rebels, and has intensified attacks on other minority groups in border areas, including Kachin State, leading to the violent repression of civilians (Yonhap News, Apr, 29, 2018).

According to the United Nations' High Commissioner for Refugees (UNHCR), the Rohingya are the largest population of Muslims in Myanmar and are subject to political and religious violence, with over 600,000 people fleeing to Bangladesh (Jeong, 2012). Owing to this persecution, Rohingya have fled to neighboring countries such as Thailand and Cambodia. Meanwhile, Chins mainly sought refuge in Malaysia. They were originally an ethnic minority 
who had historically migrated from Tibet, consisting mostly of Christians now. There are approximately 150,662 official UN refugees and applicants for refugee status registered in Malaysia (UNHCR, 2017). About 89\% of the refugees registered in Malaysia are from Myanmar, and besides the Chin, there are also ethnic minorities such as Rohingya, Myanmar Muslims, Rakine, and Arakanese.

The Chin people have also suffered from massacres, forced conscription, labor, arson, and rape by the Myanmar government army, and many have fled to Malaysia to escape poverty and disease and to seek medical treatment, education, family protection, and employment opportunities (Heo, 2017). Malaysia is a country with a diverse racial and ethnic makeup, including Malays, Chinese and Indians, and has an openness to so-called multiculturalism (Hong, 2016). Therefore, Malaysia has become one of the preferred countries for Myanmar refugees from Christian backgrounds, including the Chin (Kaur, 2007). However, Malaysia has recently refused to accept refugees owing to the continued influx of refugees and has indiscriminately threatened refugees, even ones having UN refugee status (Bartholomew, Gundel, \& Kantamneni, 2015). Those who have applied for refugee status but whose applications are yet to be processed, so-called "unqualified migrants," are being harassed, suffering detention, beatings, and deportation (Jang, 2017). Recently, the Malaysian government deported refugees other than the Rohingya to Myanmar, and, conscious of the international community's accusations that the refugees will face retaliation or risk when they return to their home country, they are classified as illegal immigrants, not refugees (Yonhap News, Feb, 16, 2021).

In the process of escape, children are more vulnerable than adults and are more likely to experience trauma. This may happen, for example, during an evacuation process, when a parent or other family member dies or gets injured in an attack, or someone in the group dies or gets injured. The survival rate of boat people is low and they experience violence, starvation, and death on board the vessels (Human Rights Watch, 2013). Also, children have various biological and psychosocial needs that differ from those of adults owing to their developmental characteristics, but the environment in which refugees live is not stable even if they have refugee status, so they suffer social disadvantages such as restrictions on employment, illegal detention, violence, exploitation and discrimination (Davies \& Webb, 2000). In addition, they 
Journal of Symbols \& Sandplay Therapy, Vol.12 No.1.

experience forced migration, the difficulty of settling in a new place as a foreigner, and negative perceptions of refugees among local people.

These situations and experiences cause various psychological difficulties in children. Refugee children suffer from emotional difficulties such as grief, loneliness, lack of a sense of identity, and loss in this unfamiliar environment and also somatic symptoms such as vomiting are prevalent (Alayarian, 2007). Psychological trauma occurs not only when one experiences actual or threatened death or injury, or an event that threatens the physical well-being of an individual, but also when he or she witnesses it happening to others (American Psychiatric Association, 2000).

For children, this stress increases the likelihood of developing emotional and behavioral problems. In previous studies, a significant number of refugee children also experienced post-traumatic stress disorder, depression, and anxiety (Ehntholt et al., 2018; Song et al., 2018), and experienced difficulties, such as acculturation stress and school adjustment (Beman, 2011; Kimayer et al., 2011). In particular, if they experience various vulnerable situations such as violence and life-threatening events before they leave their home country to seek refugee status, they are more likely to show more severe physical and emotional trauma symptoms (Song et al., 2018). Migration to an unfamiliar environment itself also increases the likelihood of developing mental health problems in children at an early stage of development (Karlsen \& Nzaroo, 2002; Bengi-Arslan et al. 1997). How parents cope with life, such as family conflicts after a disaster or violence, also affects children (Deeva \& Rapee, 2015; Grantham-McGregor et al., 2007). There are studies that show a close correlation between the psychological state of a caregiver after an incident and their child's post-traumatic symptoms, behavioral problems, and aggression (Chemtob et al., 2010; Chemtob, Nomura, \& Abramovitz, 2008; Scheeringa \& Zeanah, 2008).

Children lack the ability to control trauma or stress owing to limited language development and ego-development, unlike adults who can express trauma in language or control negative experiences of trauma (Choi, 2006). Sandplay therapy therefore provides a safe and protective space for clients, whether children or adults, to express themselves and their experiences freely. Sandplay therapy is a psychotherapeutic approach that values the manifestation of the healing potential within the human psyche (Kalff, 1980). In addition, by providing symbols that children 
can use to project and express themselves without language, such as sand, water, and figures, it is possible for them to express experiences that are difficult to express in words, or that are difficult to access through language, such as severe trauma or archetypal unconscious healing potential (Jang, 2017a, 2017b; Gil, 2006; Malchio, 1997/2008). Since analytical psychology is the theoretical basis of sandplay therapy (Jang, 2017a), we may hypothesize that children can express unconscious experiences if provided with a pathway for sandplay, art, or music (Rowland, 1999). There is also an argument that expressing the traumatic experience in words can make the negative effects of trauma more lasting (Kawai, 2015).

The symbol in sandplay therapy originates from a circle, and the circle arranges circular energy as an image, and the client projects this image on a symbol that is personally, culturally, racially, and religiously related (Jang, 2017a; Jung, 1984/2002). Symbols arise spontaneously and have healing and energy-transforming powers. That power functions to mediate symbols representing consciousness and the unconscious, and expresses a viewpoint not fully understood through language (Jang, 2017a; Jung, 1984/2002). In addition, non-verbal expressions on emotions and actions have more immediate effects than verbal expressions (Lacroix et al., 2007; Cook et al., 2005; Malchiodi, 2003), which sensory intervention can activate (Steele, 2006). Thus we can say the approach of sandplay therapy is a psychotherapy approach that intervenes in consideration of the internal and cultural resources of refugee children. Sandplay therapy can help refugee children overcome trauma, resolve conflicts in internalizing or externalizing their traumatic experiences, and develop mastery and a sense of control to solve problem situations (Kalff, 2003). Jung noted that "there are countless magical rites performed with the sole purpose of defending oneself from an unexpected and dangerous flood of the unconscious" (Jung, 1984/2008). Therefore, trauma survivors need these 'magical rituals', and sandplay therapy can provide such an opportunity.

This study focused on Myanmar Chin refugee children living in Malaysia who had experienced or witnessed the death or injury of precious family members and also suffered hardship and violence while escaping civil war and persecution. It analyzed the symbols and themes expressed in the sandplay therapy of Myanmar Chin refugee children living in Malaysia living in anxiety, fear, and discrimination who risked deportation back to Myanmar. 
Journal of Symbols \& Sandplay Therapy, Vol.12 No.1.

\section{Method}

\section{Participants}

This is an individual sandplay therapy study of Myanmar refugee children living in Malaysia. The participants in the study were Myanmar refugee children living in Kuala Lumpur, Malaysia. Among the international refugee schools in Malaysia, P School, which enrolls Myanmar refugee children, has mostly students from the Chin ethnic minority group. Thus the children who took part in this study were Chin.

The researcher recruited the participants via telephone, mail, and e-mail at $\mathrm{P}$ school, and ten children aged 8-15 were selected from the PTSD test results (CRIES-13) for children with a high probability of diagnosis. Afterwards, five children were selected who received consent from

Table 1. The sociological of population of participants

\begin{tabular}{|c|c|c|c|c|}
\hline Participant & Gender & Age & $\begin{array}{l}\text { Score of } \\
\text { CRIES-13 }\end{array}$ & Significant content \\
\hline Child A & Female & 11 & 26 & $\begin{array}{l}\text { She lives with her father and younger brother, and her } \\
\text { mother died when she was three while escaping to } \\
\text { Malaysia. }\end{array}$ \\
\hline Child B & Male & 15 & 39 & $\begin{array}{l}\text { While escaping to Malaysia three years ago, he lost his } \\
\text { family to the violent oppression in Myanmar and witnessed } \\
\text { other families dying. He once lived in the jungle as an } \\
\text { orphan. }\end{array}$ \\
\hline Child C & Male & 11 & 34 & $\begin{array}{l}\text { While escaping to Malaysia, he lost all his family and was } \\
\text { orphaned while being pursued by soldiers, living in the } \\
\text { jungle and living with the help of people around him. }\end{array}$ \\
\hline Child D & Male & 11 & 19 & $\begin{array}{l}\text { He fled to Malaysia on foot for days with his family after } \\
\text { his home was attacked in the Myanmar violence. }\end{array}$ \\
\hline Child E & Male & 12 & 37 & $\begin{array}{l}\text { He moved to Malaysia with his father and mother when he } \\
\text { was } 4 \text { years old and suffered hardship two years ago } \\
\text { because his father injured his back during the escape and } \\
\text { now has no income. Since then, his mother has returned to } \\
\text { Myanmar where her maternal grandmother is, saying that } \\
\text { she goes to earn money to avoid hardship. }\end{array}$ \\
\hline
\end{tabular}


their guardians for research and filming in writing, and provided individual sandplay therapy to the children.

The children in the study fled to Malaysia to escape conflict and violence in Myanmar. They suffered a variety of trauma during the escape process, and life as a refugee in Malaysia was another trauma. Myanmar refugee children do not receive a normal education. Also, the parents of refugee children often have to live with the help of the international refugee schools. Table 1 (see below) shows the sociological makeup of the participants in the study.

\section{Procedure}

This study provided individual sandplay therapy for the study of symbols and themes appearing in the sandplay therapy with Myanmar refugee children living in Malaysia. Individual sandplay therapy with each child took place over 5 sessions of 50 minutes each for 4 weeks in July 2018. These sessions took place in a school classroom with one client and one therapist present. Sandplay therapy is a non-directive approach, in the sense of providing a free and protected space using Dora Kalffs approach.

In order to evaluate the post-traumatic stress of the study participants, the Child Revised Impact of Events Scale (CRIES-13) took place in advance. Because of the post-traumatic stress scale, the participants were children with a high probability of diagnosis with a score of 19 or higher, which was at a level capable of diagnosing PTSD (CRIES-13 Total $\geqq 30$ ).

The researcher used scales in English and the children's language to minimize linguistic difficulties for the chidlren, and to minimize linguistic and cultural differences. They conducted sandplay therapy with two local coordinators and one interpreter who spoke the children's language. During each session, in order to analyze the verbal reports and non-verbal behaviors of the children, the researcher secured written consent along with a sufficient explanation of the study in advance before making recordings.

\section{Method}

This study used Creswell's (2007) qualitative case study method to understand the 
Journal of Symbols \& Sandplay Therapy, Vol.12 No.1.

characteristics of the symbols and themes that appeared during the sandplay therapy process of Myanmar Chin children living as refugees in Malaysia. Analysis in qualitative case studies can take two forms: an overall analysis of the entire case or a deeper analysis of a specific aspect of the case. This method involves a detailed description of the case and its themes and theme-specific analysis, and arguments or interpretations on the implications of the case may be offered (Creswell, 2007). In that sense, the qualitative case study method is effective in understanding the symbols and themes that appear during sandplay therapy involving Myanmar Chin children living as refugees and defining the context of such symbols and themes.

\section{Data Processing}

In this study, data was processed in the following order: collecting data, identifying the meaning of the data, analysis, description and interpretation, and analysis of reports through visualization. First, data was thoroughly collected across five individual sandplay therapy sessions, including photographs of sandpictures, video records, dialogue records, and observation records. The data were then processed to obtain source material by transcribing and translating records from all sandplay sessions of all research participants, including video and dialogue records. In the analysis stage, the children took the verbal and nonverbal expressions found in photographs of sandpictures and session records. They reviewed them repeatedly to analyze the common themes and symbols in detail. The identified common symbols and themes were then categorized and visualized into a table. Two sandplay therapists in a doctoral program and one specialist who is a sandplay therapy supervisor and professor participated in the study to ensure research rigor.

\section{Rigor of Research}

This study sought to apply the criteria of reliability, suitability, consistency, and neutrality suggested by Lincoln and Guba (1985) as the criteria for evaluating the quality of research design, for the rigor of qualitative research, and the criteria applied to case studies. The methods of verification in this study based on the four evaluation criteria of reliability, 
suitability, consistency, and neutrality suggested by Lincoln and Guba (1985) are as follows. First, as with other qualitative studies, the researcher made efforts to create a research environment in which they had a deep empathy for the participants and to create an environment in which the participants could see the phenomenon as it is through active participation. The researchers interviewed the children's schoolteachers to explore the background information of the children and their personal history with the children's and their parents' agreement. During the sandplay therapy, they recorded the children's verbal and non-verbal expressions about their sand scenes, and filmed video clips and photographed sand scenes to guarantee internal validation.

Second, in order to determine how well the research theme linked to the study's internal situation, or how effectively it got conveyed to the children in the sandplay process, the researcher tried to provide a comfortable atmosphere, that is a free and protected space, so that the children could talk and create sand scenes comfortably and freely about their emotions and experiences in the sandplay sessions.

Third, the researchers requested the children to express their experiences in sandplay if they could in order for the researcher to reach similar conclusions from the children's various experiences and establish consistency in the analyzing process. The researcher faithfully conducted research with two fellow doctoral students and a professor with professional perspectives and experience, in the process of data collection, analysis, and results generation, and aimed for objectivity and to perform consistent analysis by securing intersubjectivity on analyzed symbols and themes. In addition, the researcher recorded the sandplay therapy sessions in as much detail as possible for the systematic rigor of setting the research procedure and analyzing the contents.

Fourth, since proper boundaries are integral to the client-therapist relationship model in psychotherapy, the researcher tried to maintain a constant distance between themselves and the participants in the study and thus exclude possible biases. The researcher intended to collect data only with the exact facts of the research participants' experiences, and analyze them while reading the transcripts sufficiently. They strove to maintain the objectivity of research through review and discussion with their advisor and fellow researchers. 
Journal of Symbols \& Sandplay Therapy, Vol.12 No.1.

\section{Ethical Considerations}

This study passed the research ethics review by Namseoul University (IRB 1041479-HR201804-005) before it was conducted. The participants were briefed on the research purpose and methods prior to the interviews. All interviews were recorded and filmed, and participants were informed in writing that recorded material will only be used for research purposes. They were also informed in writing that while the contents of observations or recordings may be cited in the study, anonymity will be ensured. Any content that risks revealing identities will not be cited. The participants provided written consent prior to research. To protect research participants from psychological or physical discomfort, they were given a choice to choose and agree to interview times and venues. They were also informed that they could stop the interview at any time they wish. The researchers explained that all data would be discarded after the study is concluded and promised to respond to any counseling requests. All private or sensitive information was excluded and left out from the final paper so that identities cannot be assumed or revealed. After the study concluded, personal data stored in computers or on paper were discarded altogether.

\section{Results}

\section{Description of the case}

\section{1) Child A}

Child A was an 11-year-old average-build girl who did not maintain eye contact for long and seemed unstable and high in tension overall. She lived with her father and younger brothers, and her mother had died while the girl was escaping to Malaysia when she was 3 years old and they were living in the jungle. The child washed dishes at the International Refugee School. According to the Child Revised Impact of Events Scale (CRIES-13 Total=26 points), Child A had a high level at which she could vividly recall or re-experience past events owing to her trauma. 
Child A started with a shy appearance in her sand picture in the 1st session. She placed mother, father, younger brother and baby figures on the sand in front of a church. "Every Sunday, the whole family gathers in front of the church to pray to God," she said. After placing the house, she placed a car in front of it and said, "This is my dad's car, and this is our house. But this is my hope and I am sad that it is not real."

In the sand pictures of the 2nd and 3rd sessions, the child selected and placed mother, father, younger brother, and baby figures and explained they were a family, saying, "Dad goes to work, mom cooks, and the younger brothers are just playing." Afterwards, she rearranged the figures in the sand and said, "The whole family eats together."

Even in the sand pictures of the 4th and 5th sessions, the child played a game of eating food with her family after preparing food on the table, and resting on the sofa in the house, then moving from the table to the bed and playing before rest. As she moved the figures, she said, "Dad is working" and "young brothers are playing". Laying her baby on the bed, her mother cleans with a vacuum cleaner after cleaning up her food. After a while she sits her mother in her chair. After dad comes back from going out, the entire family sits at the table, and the mother prepares food and puts it on the table.

Child A currently has no home to live in and her mother died while escaping Myanmar. Child A expressed the safety of psychological settlement and her loss and longing for her mother in the sand picture, and expressed hope in the daily life of the entire family, and for an ordinary life, in the sand picture.

\section{2) Child B}

Child B was a 15-year-old boy who was taller than his peers. The child looked anxious, rolling his eyes around without saying a word, and appeared to have a high level of tension. He lost all his family members while escaping to Malaysia three years ago owing to the violent oppression in Myanmar and had witnessed the death of his family. He became an orphan and lived in the jungle. Currently, there is a report from a teacher at his school that the child is being taken care of by a local family, and that his level of learning is very low as he has just entered the school. 
Journal of Symbols \& Sandplay Therapy, Vol.12 No.1.

Child B, in the 1st session, silently rolled his eyes and stayed still for a while before playing with the sand. In his sand scene in this session, he placed trees, animals, and insects inside a fence and said, "This is a zoo." Inside the other fences were placed churches, religious figures, baby Jesus, and praying people. This is a church, and people say to God, "I pray that I will go to heaven happy."

For the sand pictures in the 2nd and 3rd sessions, he started making the sand scenes in a more comfortable way than the previous session. He brought a church, trees, fences, baby Jesus, tables and chairs, and a small pond, and said, "He is praying at the church to forgive sinners." He made a path of trees and fences in front of the church.

In the sand pictures of the $3 \mathrm{rd}$ and 4 th sessions, he placed the church and trees in the center of the sand tray and built a fence around them. He put Jesus, a cross, a pastor, and a child next to the church and said, "This is a church and a village."

Child B witnessed the death of his entire family while escaping from Myanmar, which left him orphaned. Amid the pain and confusion of witnessing the deaths of those most important to him, he felt it was his fault for not protecting them. Child B knew the church, a safe place for psychological support, and expressed it in his sand pictures as a place where God exists and forgives his mistakes and listens to children's own prayers.

\section{3) Child C}

Child C, an 11-year-old boy, had a dwarf body, did not make eye contact, and was tense and withdrawn. When he was escaping from Malaysia, soldiers chased him and he lost all his family, leaving him orphaned and living in the jungle. He is now living with the help of those around him.

In the 1st session, Child $\mathrm{C}$ did not make eye contact and fixed his gaze only on the sand tray. After a while, he started making a sand scene. Two teams of soldiers were at war. After the war, all of the gray soldiers died, and the victorious green soldiers ate the birds. The green soldier had fire and the gray soldier had a big gun. He said, "Soldiers fight for houses." Green soldiers went to the woods or mountains after losing the fight. He said, "The gray team loses and the green team wins because the green team is strong and big. The grey team will lose 
and all will die and take over the place."

Child C actively created sand scenes in the 2nd and 3rd sessions. In these sand pictures the family lives in a house, and the older brother, himself, younger sister, father, and mother live together. The faces of the families living together show that the older brother is making fun of the younger sister and the younger sister is crying, and he's smiling. Dad is very angry at that. The house is on fire and many people say they are putting out the lights and need water. The baby started the fire that set the house alight. People return by helicopter. Everyone is helping to put out the fires in the house. In the last session, he said that the baby was going to another country in a car. "The baby goes alone," he said and then added, "No one is going with the baby, and the baby is the only one going down the road." The baby's older brother is on the other side.

\section{4) Child D}

Child D was an 11-year-old boy who was shorter than his peers. He blinked when nervous and talked a lot to himself while avoiding the gaze of others. He escaped to Malaysia on foot with his family after soldiers attacked their home in Myanmar.

In Child D's 1st session, in the sand picture, the construction workers and soldiers are working, and the babies are playing. The house next to the church is the home of the firefighters. Construction people are going home by bus. The construction workers live together in a house next to the church. India House is a restaurant that serves seafood. Pointing to the upper right in the sand picture of the 2nd session, he said, "The church is where they work and the place where the plane is located is the airport." On the top left is the zoo, the building in the middle is the house, and the person next to it called the police. The police are living in the house. The yellow bus is the difference between the people who build it. When they board a plane at the airport, they go to another country.

In the sand picture of the 3 rd session, the place where the trees are and the place where the white flowers are is the house. He said, "The house downstairs is the lost house, and the house next to the crane is the new house. The lost house is a restaurant. There is delicious seafood in the restaurant. They eat the seafood there." 
Journal of Symbols \& Sandplay Therapy, Vol.12 No.1.

In the sand pictures of the 4th and 5th sessions, he said, "This is an island." There are planes, and there are soldiers living in the houses. The green figures are soldiers and gray figures are travelers. The green boss and the gray boss are friends, so they do not fight. Green soldiers teach the other side. These people are going into the jungle to build a house. There is no fighting game in the jungle. Green soldiers want to live in the jungle. He said, "I want to fly to Myanmar by plane, then I think I will be happy."

\section{5) Child E}

Child E was a 12-year-old boy, taller than his peers, who often held his hands together and brought his face close to the therapist's. He had moved to Malaysia with his father and mother when he was four years old, and during the escape, his father suffered a back injury that left him unable to work. The family has no income and has suffered constant hardships, and because of that, the child's mother went back to Myanmar where his maternal grandmother is, saying that she will earn money to avoid hardship, and has not returned yet.

Of his sand picture in the 1st session, Child E said, "A very large snake eats people. Big snakes are dangerous and scary. We have to put up a fence to protect people." But he explained that when Jesus appeared, the great serpent returned to its house. Then the people became happy. They lined up to receive the Eucharist from Jesus and ate it and prayed. The people sang and praised Jesus. So people all want to come to church to meet Jesus and praise him.

In the sand picture of the 2nd session, Egyptian and American soldiers are fighting a battle. The American soldiers have stones on the ground, which are said to be important. But while the American soldiers are sleeping, soldiers from other countries try to take the stones. In the end, the American soldiers win.

In the sand picture of the 3rd session, the warriors are fighting. The Indians put the marbles in a tent and then they sleep. Another team takes the marbles inside the tent but the Indians fight and win. Afterwards they bring back all the marbles. The marbles came down from heaven and are like our heart.

In the sand picture of the 4th session, the children's voices became louder and their 
expressions brightened. Child $\mathrm{E}$ woke up at $4 \mathrm{am}$ with a stomachache and could not eat breakfast. He said he came to school on foot. In the sand picture, the warriors fight. Surrounding the tree with the treasure at the center, the warriors protect it. As Satan, wrapped in cloth, flies around the sky, fear engulfs them. All the warriors die. When the butterfly fairy beckons, the warriors come back to life again. In the sand picture of the 5th session, he said, "This is my home and my family, my family is happy."

Child E said his brother is five years old and attends a refugee school too. He said that his father cannot work because his back hurts and he cooks food at home. He said it was hard because his father has back pain and so he has to take care of his younger brother. Child E said he wanted to become a doctor when he grew up and heal his dad. His mother is at his maternal grandmother's home in Myanmar. "I want to go back to Myanmar," he said.

\section{Case Analysis Results}

A comprehensive analysis of all individual cases before analyzing the symbols and themes found in the sandpictures created by the five children revealed five common symbols and themes. The five common symbols and themes, as listed in Table 2, are "resistance to fear and threat," "protection and care," "God's presence and guilt," "effort to recover ordinary life" and "retainment of hope for a normal life." The analysis results incorporate excerpts from

Table 2. The Symbols and Themes of Sandplay Therapy for Children of Myanmar Refugees

\begin{tabular}{cl}
\hline Common Themes & Themes from individual cases \\
\hline Resistance to fear and threat & $\begin{array}{l}\text { Two groups fighting in a war, myths and monsters, a house on fire, attack by } \\
\text { a giant serpent }\end{array}$ \\
\hline Protection and care & A safe space (church), Jesus Christ or the Virgin Mary, baby Jesus, the cross, \\
& a pastor, an ascetic \\
God's presence and guilt & The church, a spiritual figure (Jesus Christ, Virgin Mary), taking the \\
\hline Effort to recover ordinary life & - A new home, orderly structures, a fence, trying to recover normal livelihood \\
\hline Retainment of hope & - A home that a family lives in, and the things that the family do together \\
for a normal life & - Normal life absent in reality
\end{tabular}


Journal of Symbols \& Sandplay Therapy, Vol.12 No.1.

participants' verbal expressions and play behavior related to the themes and the researcher's analysis. Verbal expressions are cited as necessary to emphasize links to each theme. Parentheses are used to add explanations when needed. The symbols assumed to best represent each theme are included in the table, and photographs of sandpictures are presented in the results description, along with citations of verbal expressions.

\section{1) Resistance to fear and threat}

The refugee children directly experienced ruthless killing and violence as they were escaping from Myanmar. Even after they left their country, they were placed in vulnerable situations in which the promise of fundamental human rights and future stability was denied. Amid alienation, discrimination, poverty, anxiety and a sense of isolation, the children were experiencing confusion in their daily lives. Consequently, the children viewed their living situation as unstable and believed it could be destroyed at any moment by means such as forced deportation. They had to struggle with the anxiety and fear of this possibility constantly, with YouTube videos confirming that fellow refugees are already going through the experience and dying. During sandplay therapy, the children expressed their fear, terror and anxiety in many forms. In one scene, a group of people with fire as their weapon fought against soldiers who had guns as their weapon. In another scene, a giant serpent was swallowing people. There were also scenes of evil soldiers fighting with kind angels and a war of soldiers who represent new and different identities. The children who participated in the study belonged to an ethnic minority group that had to fight against the Myanmar government forces equipped with far superior weapons and fighters. In contrast, the only weapons available to the ethnic group were pickaxes, wooden sticks and fire. The outcome of those battles is quite obvious. Although the children were depicting the war they witnessed in real life, they were also expressing hope that their ethnic group would have the power to fight against government forces and remove their current fear and terror. While this may only be wishful thinking, it could be a psychological and unconscious effort to protect oneself from extreme threats that could cause psychological collapse by triggering an archetypal terror (Jang, 2017a).

In his first session of sandplay therapy, Child E said, "A giant serpent is eating up the people," and that "the giant serpent is dangerous and frightening." There were also scenes of 
dinosaurs and serpents attacking one another, which may symbolize aggression. The creation of sandpictures depicting the invasion of dinosaurs, serpents, beasts and monsters may be an unconscious effort by the brain to consciously and intentionally control the stimulations that trigger anxious emotions that are difficult to handle or explain. In fact, other children or adolescents and even adults who have experienced and escaped war like the Myanmar refugee children tend to symbolize disaster, intense stress, and emotions such as anger with aggressive serpents, beasts, and dinosaurs (Jang, 2017b). Jung took dreams of serpents as an example. In the face of threat, the process of retaining psychic balance tends to appear in dreams or symbolic work as animal symbols, which represent instinct. The serpent is an emblem of the visceral world, but at times serpent dreams indicate discordance between the conscious attitude of the mind and instinct. It is also a personification of the threatening aspect of conflict. We have an archetypal disposition to recognize the danger of "something long and curvy that slithers, with fangs and a flickering, forked tongue" (Jung, 1984/2008).

"A giant serpent is eating up the people. The serpent is dangerous and frightening."

- Child E, Session 1-

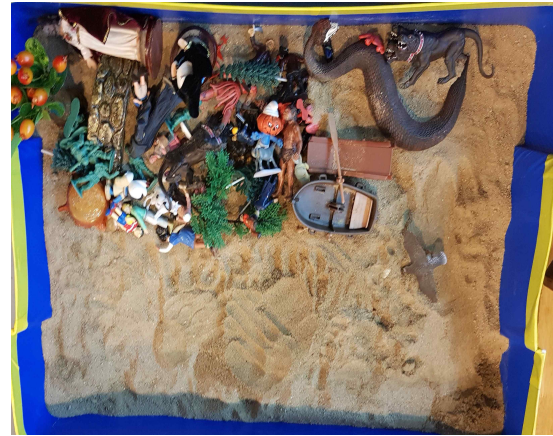

(Fig. 1) Child E, $1^{\text {ST }}$ session

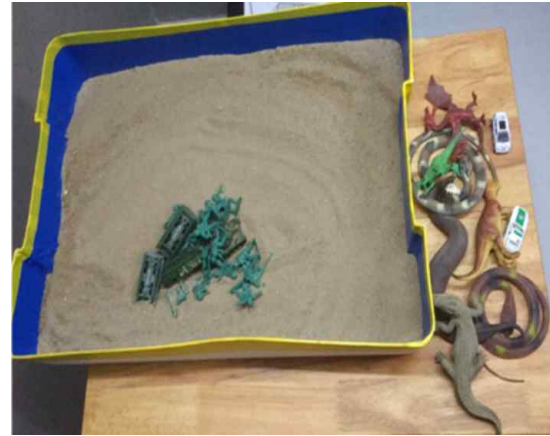

〔Fig. 2〕 Child $C 2^{\text {nd }}$ session

In Child C's sandpicture, soldiers were fighting in two groups. It was interesting that one group used fire as their weapon while the other group used guns. Fire and guns are quite different in terms of capability. Fire cannot fight against guns. At the same time, the sandpicture was an expression of how even strong weapons cannot bring the other side to 
Journal of Symbols \& Sandplay Therapy, Vol.12 No.1.

defeat. While the sandpicture depicted the ethnic group's helplessness in the face of oppression and violence, it also expressed a belief that their lives and existence would never be destroyed in spite of it all. There were also scenes of life being destroyed and finding refuge in the forest or mountain. It was an expression of a helpless effort to overcome fear while dealing with the possibility of death, terror and imagining the worst. Child $\mathrm{C}$ experienced the death of his parents during his escape and had to live alone in a jungle. Not only was he affected by trauma that came from this experience, but he also seemed to be going through a feeling of loneliness and lethargy caused by a long period of life instability. Emotional experiences that cannot be overcome are described with expressions such as "seems to be exhausted," "seems to be depleted," and "exhausted from anger and desire," and are symbolized in sandpictures with figures such as fire, desert and ashes (Jang, 2017a).

"The green soldiers have fire and the gray soldiers have large guns."

"The soldiers are fighting over the house."

"The green soldiers will probably have to go into the mountain after they lose the battle."

- Child C, Session 1

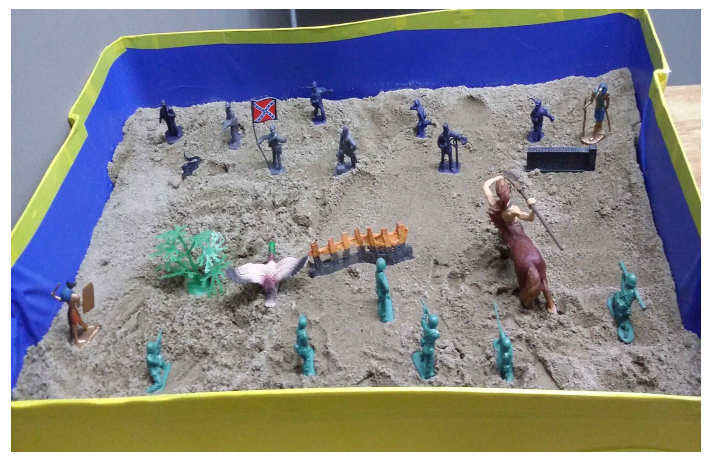

(Fig. 3) Child C, $1^{\text {ST }}$ session

\section{2) Protection and care}

The only places that the Myanmar refugee children received protection and care in Malaysia were the international refugee school and a church run by a foreign missionary. The refugee school monitored the children's studies and their state of nutrition and also assisted with legal 
issues. However, once the children left the school grounds and went out into Malaysian society, they risked being detained by the police or being fined or deported. Therefore, they were extremely reluctant about leaving the school grounds. As it may be presumed, such restrictions in life create a thirst for freedom. The refugee school and church frequently appeared in the children's sandpictures as symbols of their desire for protection, trauma and a protecting place.

The children tended to create a fortified area in their sandpictures, representing their desire for protection and their trauma (Grubbs, 1995; Zinni, 1997). Many times, the church and refugee school played this role. Sandplay therapy, which emphasizes providing a free and protected space, acts as a Temenos in which the children can safely express and share their experiences and feelings (Jang, 2017a).

Most of the children depicted the church, Jesus Christ, the Virgin Mary, baby Jesus, the cross, a pastor or an ascetic as a refuge that would protect their basic rights and provide care. The chapel of a Christian church is symbolically the center of the world, represents the protective aspect of the Great Mother and symbolizes protection (Cooper, 1978). The symbols that the children expressed were associated with images of devotion, such as warm and nurturing care and protection. Therefore, the symbols that the children commonly used were not just simple representations of reality. The positive energy of Jung's mother archetype indicates a feminine magical authority, benevolence, care, sustainment, a provider that supplies nutrition for growth and abundance, the foundation of magical transformation and regeneration, helpful instinct or drive, and something secretive in the inner world of an individual who faces a psychological crisis (Jung, 1984/2002), and therefore delivers healing.

Child A placed some figures in front of the church and said, "The families gather in front of the church every Sunday and pray to God."

- Child A, Session 1-

Child B created a church and village. He explained that the people were praying to God, saying, "We wish to go to heaven, and we are happy here." 


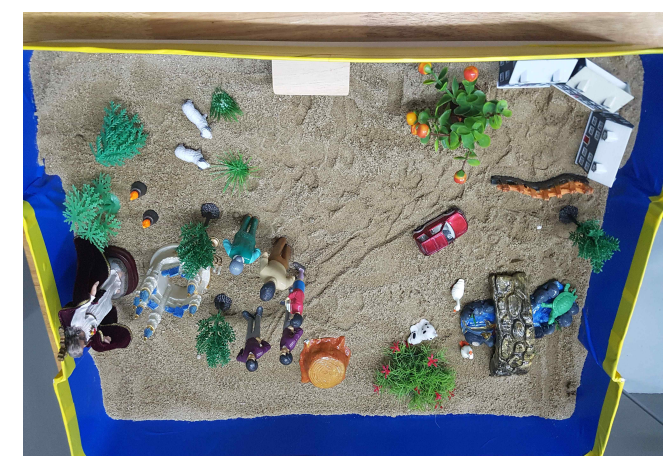

[Fig. 4) Child A, $1^{\text {ST }}$ session

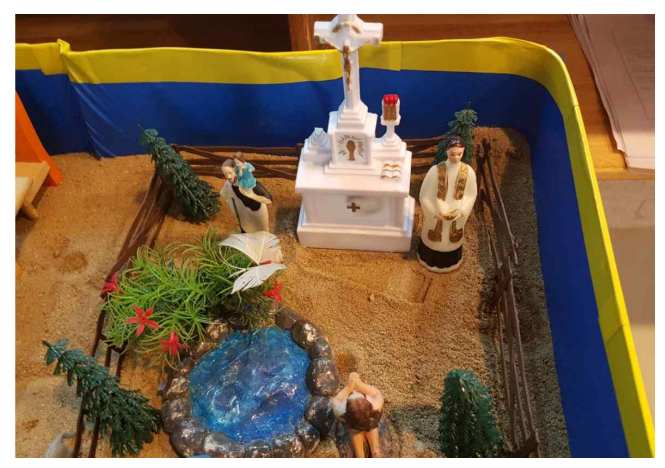

(Fig. 5) Child B, $1^{\text {ST }}$ session

\section{3) God's presence and guilt}

Apart from the caring and protective aspects of the school and the church, religion and God prevent the human psyche from collapsing. In the sandpictures of the refugee children, God always appeared as a being who is always 'there.' It is archetypal for human beings to think of religion or the image of God whenever disaster and pain hits (Jung, 1984/2008: Kim, 2014; Jang, 2017). This is because the inner world of the human being attempts to sustain psychic balance (Jung, 1984/2008: Kim, 2014). This attempt is displayed through the creation of scenes of holy rituals or images that give a feeling of divinity. The divine images carry out the function of connecting the opposites, or the painful reality and ideal recovery. By connecting and healing conflicts between the opposites, the process eases symptoms and delivers an expansion of personality (Jang, 2017a).

Trauma or emotional and physical abuse in childhood leads to a higher possibility of experiencing guilt or developing a tendency to self-criticize in later life (Salters-Pedneault et al., 2007). The experience of trauma and ensuing impact are continuously projected on a person's environment. Therefore, environmental impacts such as the death of someone important, disease, absence, a child's negative disposition or non-supportive environment consequently trigger internal and external conflicts that interfere with the automatic formation of development. This, in turn, impedes ego development and leads to states such as the dismantlement of ego. As a result, children may develop narcissistic personalities, belligerence that has not been integrated, or guilt regarding their existence (Jang, 2017a). 
The Myanmar Chin children living as refugees in Malaysia mainly were from Christian backgrounds, and the primary provider of support in their environment was also related to the church. The children expressed God as a being who provides protection, but also a being that they need to ask for forgiveness because he can punish them for their sins. During their escape, the children witnessed the death or injury of the people who are most important to them their family members. The children were struggling with guilt because they believed that it was their fault that their family died and that they caused all the confusion and hardships they were going through.

"The people line up to receive the sacrament from Jesus (to receive forgiveness), and they pray after they receive it."

- Child E, Session 1-

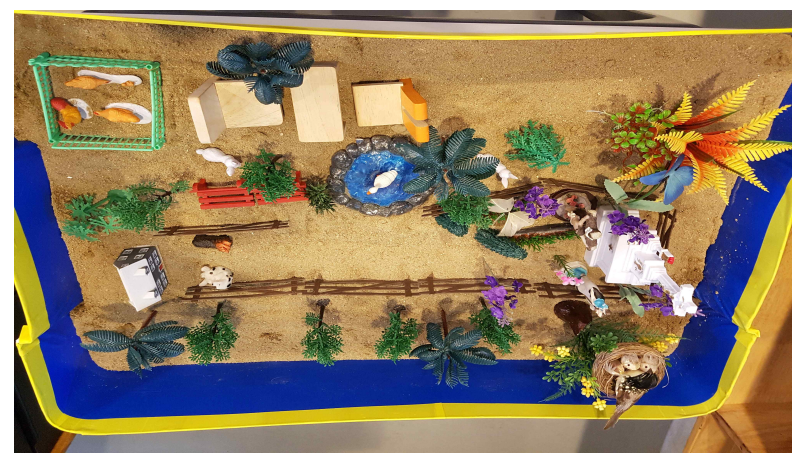

[Fig. 6〕 Chid B, $2^{\text {nd }}$ session

"I am a sinner, and I pray for forgiveness."

- Child B, Session 2 -

Child $E$ and $B$ stated that they need to ask for forgiveness because it was their fault that these things happened.

\section{4) Effort to recover ordinary life}

Despite short therapy period, the children even shown attempts to restore their lives in 
Journal of Symbols \& Sandplay Therapy, Vol.12 No.1.

sand. They knew that they may have to wait for a long period of time but nevertheless expected a recovery in life. For example, one child tried to build new houses to replace the lost ones. The representations of well-structured fences, orderly houses and architecture are an attempt to overcome the chaotic surroundings, financial difficulties, and anxiety that stem from unpredictable future. The numinous beauty of images that bring order and balance again influence children who made those images, bringing positive interaction cycle (Ammann, 1998). As a result, children can maintain order in their psyche without a critical collapse of the ego despite poor surroundings.

Children often made mention of the jungle, which is partly attributable to the fact that they lived in the jungle area. It should also be noted that the color green is a symbol of healing and divinity. The life-supporting energy and the vitality of the color green apply widely to encompass the realms of inanimate objects and living organisms, minerals with healing energy, plants and animals. Green is considered a divine color, representing life itself, in not only Christianity but also Islam (Hildegard of Bingen, 1983; Ammann, 1998).

"This is an island. There are airplanes here, and soldiers live in the houses." "The boss of the green soldiers and the boss of the gray soldiers are friends. They don't fight." "These people are going to the jungle to build houses. They play in the jungle; they don't do dighting play. Green soldiers want to live in the jungle." "Green soldiers and gray soldiers are from the same country, and they want to live together. "I want to ride on an airplane and fly to Myanmar. I think that would make me happy."

- Child D, Session 5 -

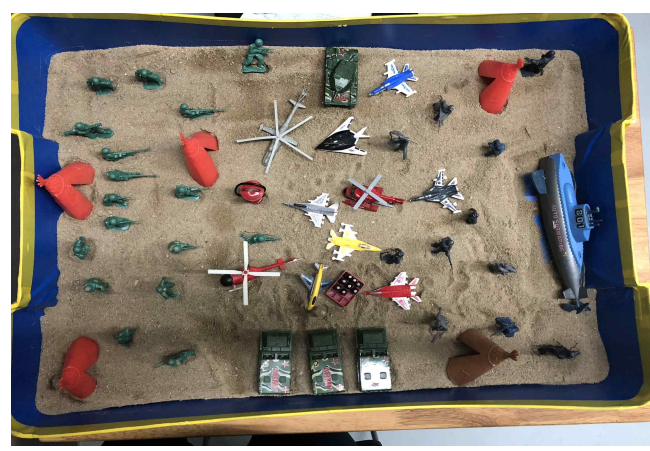

(Fig. 7) Chid D, $5^{\text {th }}$ session 
"The houses below [the jungle] are the lost houses. The house next to the crane is new."

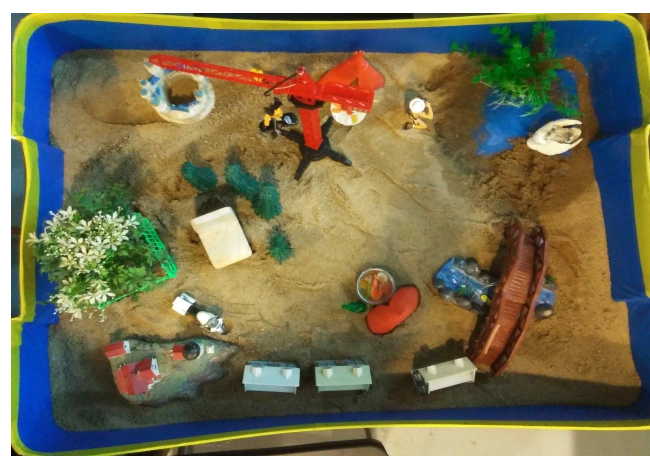

〔Fig. 8) Chid D, $3^{\text {th }}$ session

5) Retainment of hope for a normal life

Since fleeing from Myanmar to Malaysia, these children have not been able to enjoy ordinary, everyday things appropriate for their stages of development. Their life in Malaysia is very limited due to various reasons, including legal reasons. Despite being unable to enjoy an ordinary life with guaranteed basic right, the children expressed their hopes through sandpictures. Normally, returning to normal life after a traumatic experience is expected in the latter part of the healing process but situationwise, this was actually impossible for these children. Nevertheless, they still created sandpictures suggesting a return to normal life. This would partly be an expression of their expectation or hope for an ordinary life in outer reality, and it would also represent psychological recovery. At this state, the client's sandpicture no longer shows extreme archetypal elements of the psyche and instead shows everyday lives of ordinary people (Turner, 2004).

Child A's mother had died while fleeing Myanmar and therefore Child A was living with her father and little brother only. Unfortunately, however, they did have established settlement in Malaysia. In session 5, Child A commented, "Dad is working" and "My little brothers are playing." Her sandpicture depicted scenes of ordinary, everyday life: baby was laid on a bed, mother cleaned the dishes and cleaned the house, father came back home from outside, the 
Journal of Symbols \& Sandplay Therapy, Vol.12 No.1.

whole family sat on a table, and mother cooked and placed the food on the table.

"Dad is working.", "My little brothers are playing."

- Child A, Session 5 -

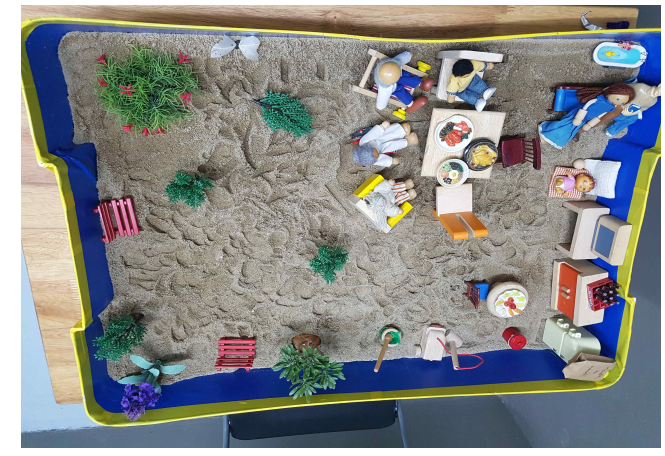

(Fig. 9) Chid A, $5^{\text {th }}$ session

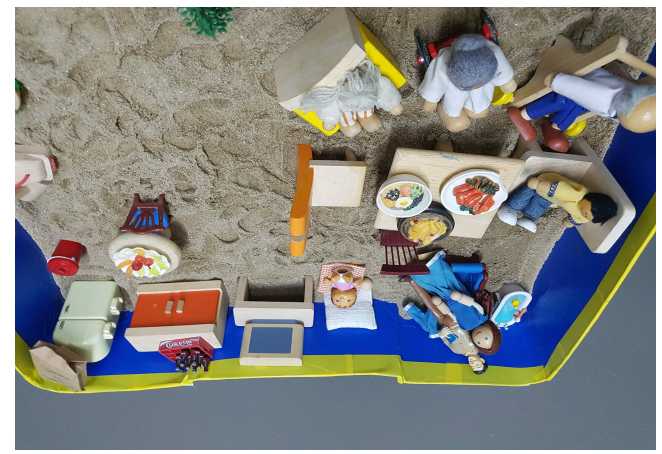

[Fig. 10] Chid A, $5^{\text {th }}$ session

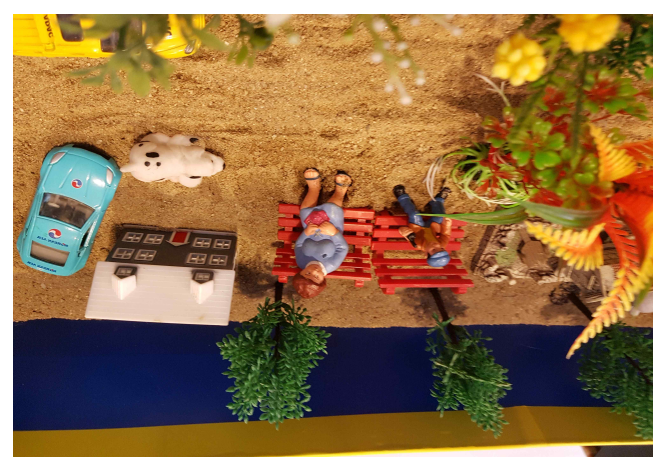

[Fig. 11) Chid B, $4^{\text {th }}$ session

\section{CONCLUSION}

This study administered sandplay therapy to Malaysia Chin refugee children who fled their home country and are in the process of settling in Malaysia. The study sought to categorize and analyze symbols and themes commonly found in the children's sandplay process, based on both 
verbal and nonverbal expressions of their experiences, sandpictures, observed facts, and figures used.

Participants of the study are five Myanmar Chin children who fled from Myanmar and are living in Kuala Lumpur, Malaysia and attending an international refugee school supported by the United Nations. They all experienced massacre and violence, lost their families or witnessed death during their escape from Myanmar.

An integrated analysis of the symbols and themes that showed up during the entire process was made, from which five common themes and symbols were identified: "resistance to fear and threat," "protection and care," "God's presence and guilt," "effort to recover ordinary life" and "retainment of hope for a normal life." The Myanmar Chin children, who experienced different traumas, expressed their psychological and emotional pains and the difficulties that come with in their sandpictures. The confusions they went through during the escape was shown saliently and repeatedly in their sandpictures. The sandpictures also showed the changes they experienced with the passing of time. It is easier to express inner pains through sandpictures rather than verbally, and emotions can be expressed through safe projections (Boik \& Goodwin, 2000). Such can be seen evidently in sandpictures of clients who went through different traumas, and is coherent with study findings that the theme of traumatic experiences, like trauma itself, repeats in an impulsive manner (Lee, 2016; Lee \& Jang, 2018; APA, 2013; Eth, 2001). The violence they were exposed to in Myanmar, fear and violence experienced during the process of the escape, and related emotions, e.g., anger, that have been repressed were represented through the symbolisms of armed soldiers in a battle and a large snake. No child was an exception. This is in sync with the findings of other studies that clients tend to use dangerous animals rather than armed forces when representing wars or dangers in sandplay therapy (Bradway \& McCoard, 1997).

In terms of the traumas experienced, the children commonly placed figures such as church, Jesus, Virgin Mary and the cross as a refuge for care and protection. It can be said that sandplay therapy, through symbolisms of figures that are in line with their religious and cultural experiences, played the role of temenos where the desire for protection and care can be expressed and shared (Jang, 2017a). 
Journal of Symbols \& Sandplay Therapy, Vol.12 No.1.

The children felt guilty about the death of their families, acquaintances, and relatives and believed they are responsible for the difficulties in their present life. They expressed the wish to receive forgiveness by praying to God. Such is consistent with the statement that recalling images of God when a disaster strikes is archetypal, and also that recalling images of God or becoming interested in God in a time of crisis is to maintain balance in the psyche (Jung, 1984/2008; Kim, 2014). It can be said that the sandplay therapy process helped the refugee children from Myanmar to connect the opposites and conflicts and to heal (Jang, 2017).

As therapy progressed, the children, rather than creating scenes of war or aggression, began to express their desire to return to everyday life that is ordinary and stable. At first, they were busy expressing their feelings of confusion about the devastating experience, which they had no means to do so before therapy. But after those expressions were made to a certain extent, they began focusing more on their awareness of the reality and what is lacking. This is similar to other study findings that people who experienced massive trauma such as war and natural disasters begin to show hope of returning to their daily lives as they become more stable with the passing of time, through psychotherapy like sandplay therapy or due to the inner recovery mechanism (Lee, Jang, 2020). While expressing desires for protection and care against dangers and damages, recovery of order from chaos, and hopes of returning to everyday life in sandplay could be an expectation or wish to restore one's outer reality, it could also indicate psychological recovery. It is to be mentioned again that sandpictures of those who are at this state no longer show extreme archetypal elements of the psyche and instead tend to show daily lives of ordinary people (Turner, 2004).

Sandplay therapy intervention for Myanmar Chin children was effective, as mentioned above. These children had left their home country and were attending an international school in Malaysia where they had to use English, which means that they are exposed to multiple unfamiliar languages. Therefore, sandplay therapy approach, which uses symbols and play, rather than focusing on language was an appropriate way for these children to express their traumatic experiences and feelings. Given that program was conducted for only four weeks, however, the therapy's effect is limited. It is also difficult to conclude that they therapy provided an opportunity to comprehend both the complex circumstantial and psychological difficulties that the 
children were under. Despite the short intervention period and linguistic difficulties, however, the therapy did have some positive effects, perhaps because, like all children, the Myanmar Chin children have innate archetypal healing power. In addition, given the horrors of their experiences and unstable circumstances, the children responded strongly to the intervention though time was short. Such outcome suggests that not only material, financial, and support but also psychological approaches that take into consideration the special socio-cultural background as well as psychological and emotions problems of refugee children ought to be provided. In addition, the effect of sandplay therapy on a small group of children in a short period of time shown through the study indicates that it is an appropriate approach for refugee children, as psychotherapeutic support for this special group of people is usually given for a short term. Furthermore, the study outcome suggests that crisis intervention ought to be made for refugees right after they seek refuge. Crisis intervention would make it possible to prevent serious problems that follow trauma such as mental illness, family breakdown, maladaptation to a new environment, etc. Plus, given that psychotherapy support should be provided in the short term due to the specificity of refugees, it can be said that sandplay therapy can be effective when provided in a short term and to small groups. Furthermore, it can be said that crisis intervention should take place immediately after evacuation. Support for crisis intervention will allow for serious problems such as subsequent outbreaks of psychological trauma, destruction of homes, and maladaptation to new environments.

\section{References}

Alayarian, A. (2007). Resilience, Suffering, and Creativity: The Work of the Refugee Therapy Centre (2011).

(Translated). Seoul: Sigma Press. Doi: 10.1080/13642530701571682

Albert, E. (2017). Council on Foreign Relations. Retrieved from the Rohingya

Migrant Crisis. Available online: http://www.cfr.org/burmamyanmar/rohingya-migrant-crisis/p36651 (accessed on September 2018) Bangladesh Fact Sheet (2016). UNHCR: Geneva, Switzerland.

American Psychiatric Association (2000). Diagnostic and Statistical Manual of Manual of Mental Disorders (4th test revision, American Psychiatric Association). Doi: https://Doi.org/10.1192/bjp.179.1.85-a 
Journal of Symbols \& Sandplay Therapy, Vol.12 No.1.

Ammann, R. (1998). Healing and Transformation in Sandplay: Creative Processes Become Visible. Chicago: Open Court.

Bartholomew, T., Gundel, B., \& Kantamneni, N. (2015). A dream best forgotten: The phenomenology of Korean refugees' pre-resettlement stressors. Counseling Psychologist, 43(8), 1114-1134. Doi: https://Doi.org/10.1177/0011000015606221

Beman, H. (2011). Children and war: Current understandings and future directions. Public Health Nursing 18, 243-252. Doi: https://Doi.org/10.1046/j.1525-1446.2001.00243.x

Bengi-Arslan, L., Verhulst, F.C., van der Ende, J., \& Erol, N. (1997). Understanding childhood (problem) behaviors and competencies in Turkish immigrant, Turkish and Dutch Children. Social Psychiatry \& Psychiatric Epidemiology, 32, 477-484. Doi: https://Doi.org/10.1007/BF00789143

Boik, B., \& Goodwin, E. (2000). Sandplay: A Step-by-Step Manual for Psychotherapies of Diverse Orientations. New York: W.W. Norton \& Company. Doi: https://Doi.org/10.1016/S0197-4556(01)00105-8

Bradway, K. \& McCoard, B. (1997). Sandplay: Silent Workshop of the Psyche. New York: Routledge. Doi: https://Doi.org/10.4324/9780203977576

Chemtob, C., Nomura, Y., \& Abramovitz, R. (2008). Impact of conjoined exposure to the World Trade Center attacks and to other traumatic events on the behavioral problems of preschool children. Archive of Pediatric and Adolescent Medicine, 162(2), 126-133. Doi: https://Doi.org/10.1001/archpediatrics.2007.36

Chemtob, C. M., Nomura, Y., Rajendran, K., Yehuda, R., Schwartz, D., \& Abramovitz, R. (2010). Impact of maternal posttraumatic stress disorder and depression following exposure to the September 11 attacks on preschool children's behavior. Child Development, 81, 1129-1141. Doi: https://Doi.org/10.1111/j.1467-8624.2010.01458.x

Choi(2006). Establishing the public support system for disaster survivors: Disaster survivors' return to the society. Crisis and Emergency Management, 2(2), 1-18.

Creswell, J. (2007). Qualitative Inquiry and Research Design: Choosing among Five Traditions (2ed.). Thousand Oaks, CA: Sage.

Cook A., \& Spinazzola, J. (2005). Complex trauma in children and adolescents. Psychiatric Annals, 35(5), 390-398

Cooper, J. C. (1978). An Illustrated Encyclopaedia of Traditional Symbols. NY: Thames \& Hudson. Lee Yun-gi (2012). (Translated). An Illustrated Encyclopaedia of Traditional Symbols. Seoul: Kachi Books.

Davies, M., \& Webb, E. (2000). Promoting the psychological well-being of refugee children. Clinical 
Child Psychology and Psychiatry, 5(4), 541-554. Doi: https://Doi.org/10.1177\%2F1359104500005004008

Deeba, F., Rapee, R., \& Prvan T. (2014). Psychometric properties of the children's Revised Impact of Events Scale (CRIES) with Bangladesh children and adolescents. Peer J, 2:e536. Doi: https://Doi.org/10.7717/peerj.536

Deeba, F., \& Rapee, M. (2015). Prevalence of traumatic events and risk for psychological symptoms among community and at-risk children and adolescents from Bangladesh. Child and Adolescent Mental Health, 204), 218-224. Doi: https://Doi.org/10.1111/camh.12093

Ehntholt, K., Trickey, D., Harris, H., Chamvers, H, Scott, M, \& Yule, W. (2018). Mental health of unaccompanied asylum-seeking adolescents previously held in British Detention Centres. Clinical Child Psychiatry, 23(2), 238-257. Doi: https://Doi.org/10.1177\%2F1359104518758839

Eth, S (2001). Introduction: childhood trauma in perspective. In Eth, S. (ed.), PTSD in Children and Adolescents. Washington, DC: American Psychiatric Publishing. Doi: https://Doi.org/10.1023/A:1009564724720

Friedman, H., \& Mithell, R. (2008). Supervision of Sandplay Therapy. England: Psychology Press. Jang Mikyung, Lee Mi-ae, Lee Sang-hee, Chae Gyeong-seon, Hong Eun-ju (2011). (Translated). Seoul: Korean Society of Sandplay Therapy.

Gil, E. (2006). Helping Abused and Traumatized Children: Integrating Directive and Nondirective Approaches. New York: Guilford Press.

Grantham-McGregor, S., Cheung, Y.B., Cueto, S., Glewwe, P., Richter, L., \& Strupp, B. (2007) Developmental potential in the first 5 years for children in developing countries. The Lancet, 369, 60-70. Doi:https://Doi.org/10.1016/S0140-6736(07)60032-4

Heo C-J. (2017). Refugees of Myanmar and missionary care. Christian Thought, 708, 47-57.

Jang B-H. (2017). A study in legislative limitation on the repeated application for refugee protection in East Asia. HUFS Law Review, 17(6), 417-445.

Jang, M. (2017a). Analytical Psychological Sandplay Therapy. Seoul: Hakjisa.

Jang, M. (2017b). Archetypal symbolism in the recovery process from natural disaster: sandplay therapy of earthquake adolescent survivors. Journal of Symbols \& Sandplay Therapy, 8(2), 1-21.

Jung, C. G. (1984/2008). Images of Man and God (Menschenbild und Gottesbild). C. G. Jung Institute of Korea, two translated books of C. G. Jung, (C. G. Jung Institute of Korea, Translated by C. G. Jung Book Translation Committee). Seoul: Sol Books.

Jang, J-Y. (2012). Change of Foreign Policy of Myanmar and Relations with Major Countries. Seoul: Korea Institute for International Economic Policy. 
Journal of Symbols \& Sandplay Therapy, Vol.12 No.1.

Jung, C. G. (1984/2002). The Archetypes and the Collective Unconscious (Archetyp und Unbewusstes). C. G. Jung Institute of Korea, two translated books of C. G. Jung. (C. G. Jung Institute of Korea, Translated by C. G. Jung Book Translation Committee). Seoul: Sol Books.

Kalff, D. M. (1980). Sandplay: A Psychotherapeutic Approach to the Psyche. Boston, IL.: Sigo Press.

Kalff, D. M. (2003). Sandplay: A Psychotherapeutic Approach to the Psyche. Cloverdale, CA: Temenos Press (original work published in 1980).

Karlsen, S., \& Nazroo, J. Y. (2002). Relation between racial discrimination, social class, and health among ethnic minority groups. American Journal of Public Health, 92, 624-631. Doi: https://Doi.org/10.2105/AJPH.92.4.624

Kaur, A. (2007). Refugees and refugee policy in Malaysia. UNEAC Asia Papers, 18, 77-90.

Kawai, T. (2015). Big stories and small stories in the psychology relief work after the earthquake disaster: Life and death. In Huskinson, L. \& Stein, M., Analytical Psychology in a Changing World: The search for Self, identity and community. NY: Routledge. Doi: http://library.oapen.org/handle/20.500.12657/22277

Kim, S. (2014). Psychology and religion: Focused on the thought of C. G. Jung. Theology and Praxis, 34, 285-318.

Kirmayer, L., Narasiah, L., Munoz, M., Rashid. M., Ryder, A., Guzder, J., Hassan, G., Rousseau, C., \& Pottie, K. (2011). "Common Mental Health Problems in Immigrants and Refugee: General Approach in Primary Care." Canadian Medical Association Journal, 83(12), 959-967. Doi: https://Doi.org/10.1503/cmaj.090292

Lacroix, L., Rousseau, C., Gauthier, M-F., Singh, A., Giguere, N., \& Lemzoudi, Y. (2007). Immigrant and refugee preschoolers' sandplay representation the tsunami. Arts in Psychotherapy, 34, 99-113. Doi: https://Doi.org/10.1016/j.aip.2006.09.006

Lee, B-Y., \& Jang, M. (2015). Comparisons between North Korean adolescent defectors and South Korean adolescents in expressions in sandplay therapy. Journal of Symbols \& Sandplay Therapy, Q(2), $31-45$.

Lee, Y-A. (2016). An analysis of posttraumatic play characteristics of an abused child in play therapy. Korean Journal of Play Therapy, 192), 335-362. Doi: https//Doi.org/10.17641/KAPT.19.4.4

Lee, S-H., \& Jang, M. (2020). The effect of group sandplay therapy on psychological health and resilience of adolescent survivors of Nepal earthquake. Journal of Symbols \& Sandplay Therapy, 11(2), 45-78. Doi: http://Doi.org/10.12964/jsst.20007

Lee, S-H., \& Jang, M. (2018). A study of themes and symbols in group sandplay therapy of 
Rohingya refugee children in Malaysia. Journal of Symbols \& Sandplay Therapy, 9 1), 66-67. Doi: https://Doi.org/10.12964/jsst.1800

Malchiod, C., \& Crenshaw, D. (2013). Creative Arts Play Therapy for Attachment Problems. Kim Yu-jin, Ryu Jin-a, Shin Hyeon-jeong, Yun Mi-won, Jang Mi-gyeong, Choi Myeong-seon, Hong Eun-ju (2019). (Translated). Creative Arts play Therapy for Attachment Problems. Seoul: Hakjisa.

Malchiodi, C. (2003). Using creative activities as intervention for grieving children in preschool triads. Developmental Psychology, 20, 807-814.

Malchiodi, C. A. (1997). Breaking the Silence: Art Therapy with Children from Violent Homes (2nd ed.). New York: Brunner-Routledge.

Malchiodi, C. A. (Ed.). (2005). Expressive Therapies. New York: Guilford Press.

Malchiodi, C. A. (Ed.). (2008). Creative Interventions with Traumatized Children. New York: Guilford Press.

Mohamed Ashraf Alam (2015). Historical Background of Arakan. Available online: http://sayedarakani48.webs.com.arakanhistory.htm (accessed 4 Nov 2020).

Oh,S-S., Shin, H-G., \& Kim, S-H. (2009). Workbook of Post-Traumatic Stress Disorder. Seoul: Hakjisa. Reynolds, C., \& Kamphaus, R. (2004). Behavior Assessment for Children (BASC-2). Circle Pines, MN: American Guidance Service. Doi: https://Doi.org/10.1177/15345084070320020301

Rowland, S. (1999). C. G. Jung and Literary Theory. In C. G. Jung and Literary Theory, 188-201. London: Palgrave Macmillan.

Rutter M. L. (1999). Psychosocial adversity and child psychopathology. British Journal of Psychiatry, 174, 480-493. Doi: http://Doi.org/10.1192/bjp.174.6.480

Salters-Pedneault, K., Gentes, E., \& Roemer, L. (2007). The role of fear of emotion in distress, arousal, and cognitive interference following an emotional stimulus. Cognitive Behavior Therapy, 36, 12-22. Doi: https://Doi/10.1080/1650607060087428

Sandhu, D., \& Asrabadi, B. (1994). Development of an acculturative stress scale for international students: Preliminary findings. Psychological Reports, 75(1), 435-448. Doi: https://Doi.org/10.2466/pr0.1994.75.1.435

Scheeringa, M., \& Zeanah, C. (2008). Reconsideration of harm's way: Onsets and comorbidity patterns of disorders in preschool children and their caregivers following hurricane Katrina. Journal of Clinical Child \& Adolescent Psychology, 37(3), 508-518. DIO: https://Doi.org/10.1080/15374410802148178

Seitz, H. (2017). 10 Facts about Refugees in Malaysia. Available online: https://borgenproject.org/about-refugees-in-malaysia (accessed 5 Nov 2020) 
Journal of Symbols \& Sandplay Therapy, Vol.12 No.1.

Song, H-J., Kim, S-Y., Lee, I-S., \& Han, J-Y. (2018). Study on Human Rights of Refugee Women in Korea. Ewha Gender Legal Institute. 10(3), 149-189. Doi: https//Doi.org/10.22791/ewhagl. 2018.10.3.005

Stake, R. (1995). The Art of Case Study Research. Thousand Oaks, CA: Sage.

Steele, W. (2006). When cognitive interventions fail with children of trauma: Memory, learning, and trauma intervention. Available online: http://www.tlcinstitue.org/cognitiveinterventions.html

Turner, B. A. (2005). The Handbook of Sandplay Therapy. Los Angeles, CA: Temonos Press.

Uhlein, G. (1983). Meditations with Hildegard of Bingen. New Mexico: Bear \& Company.

United Nations High Commissioner for Refugees: UNHCR (2010). Malaysia provides educational opportunity to children in schools operated by refugees. Searched on December 2, 2020 https:// www.unhcr.or.kr

United Nations High Commissioner for Refugees: UNHCR (2015) UNHCR Subregional Operations Profile - South-East Asia - Malaysia. Available online: http://www.unhcr.org/cgibin/texis/vtx/page?page=49e4884c6\&submit=GO(accessed 28, Oct 2020).

United Nations High Commissioner for Refugees: UNHCR (2017). Over 168,000 Rohingya likely fled Myanmar since 2012. Available online: http://www.unhcr.org/news/latest/2017/5/590990ff4/168000-rohingya-likely-fled-myanmar-since-2012unhcr-report.html?query=Rohingya (accessed 29 Oct 2020).

Werner E. E., Smith R. S. (1982). Vulnerable but Invincible: A Longitudinal Study of Resilient Children and Youth. New York: McGraw Hill. Doi: https://Doi.org/10.1515/9783110860153-011

Yonhap News (Apr. 29, 2018). Malaysia, "Twelve hundred Myanmareses to be repatriated are not refugees but illegal immigrants". Searched on March 20, 2021 https://www.yna.co.kr/view/AKR20180429022800104

Yonhap News (Feb. 16, 2021). Malaysia, "Twelve hundred Myanmareses to be repatriated are not refugees but illegal immigrants". Searched on March 20, 2021, https://www.yna.co.kr/view/AKR20210216080200104 
상징과모래놀이치료, 제 12 권 제 1 호

Journal of Symbols \& Sandplay Therapy

2021, 6, Vol. 12, No. 1, 83-110.

doi https://doi.org/10.12964/jsst.21002

\title{
말레이시아 거주 미얀마 친족난민 아동의 모래놀이치료 상징 및 주제연구
}

\section{A Study on the Symbols and Themes of Sandplay Therapy for Children of Myanmar Refugees living in Malaysia}

\author{
김 혜 영 \\ 조 은 진 ${ }^{* *}$ \\ 장 미 경 ${ }^{* *}$ \\ Hyeyoung Kim \\ Eunjin Cho \\ Mikyung Jang
}

\begin{abstract}
$<$ Abstract $>$
This study categorized and analyzed the themes and symbols that appeared in the sandplay therapy of Myanmar Chin children living as refugees in Malaysia. The researchers provided individual sandplay therapy to five children attending a UN refugee school in Malaysia for four weeks in July 2018. There were five sessions for each child and 50 minutes per session. The researchers used a Kalffian sandplay approach to provide a free and protected space for the children. They used Creswell's (2007) qualitative case study method to understand the themes and symbols and, through a comprehensive analysis of all cases, they found five common themes and symbols. These themes were 'fear/threat and the resistance from the heart to it', 'protection and care', 'the existence of god and guilty feelings', 'the effort to recover normal life', and 'do not give up hope for a normal life'. The refugee children expressed their emotional pain in the sand tray so that the traumas they had experienced while escaping and the chaos in their present lives appeared prominently and repeatedly there. As the sessions progressed, however, they expressed a hope to return to their normal lives as they recovered some sense of stability. They could more easily express their inner pain in sandplay than in language, and project themselves safely and express their emotions. It is a fact that, like all other children, the innate and archetypal healing powers of these refugee children's psyche allowed them to respond strongly to sandplay, despite the short-term therapeutic intervention, the horrors of their experiences and the unstable situations they face. Future research should evaluate the effectiveness of a psychotherapeutic approach that considers the social and cultural specificity of refugee children and their various emotional problems and secure economic aid and legal status for them.
\end{abstract}

Keywords : fear and threat, protection and care, God's presence and guilt, recovery of life, hope of a normal life

* 주저자, 남서울 대학교 아동복지학과 대학원 박사과정 (rla3430@hanmail.net)

** 교신저자, 남서울대학교대학원 아동복지학과 박사수료 (eunjin1805@naver.com)

*** 공동저자, 남서울대학교 아동복지학과 교수 (jangmiky@hotmail.com) 
Journal of Symbols \& Sandplay Therapy, Vol.12 No.1.

\section{I. 서 론}

난민이란 인종, 종교, 국적, 특수 사회집단의 구성원 혹은 정치적 견해의 이유로 박해를 받아 고통을 겪고 있는 사람들로, 고국을 떠나 있고 고국으로 돌아갈 수 없는 사람들이거 나 혹은 박해와 관련된 사건으로 인해 고국을 탈출하여 국적이 없는 상태로, 돌아갈 수 없 거나 고통 때문에 고국으로 돌아가려고 하지 않는 사람들을 말한다(Alayarian, 2007).

현재 인근 여러 나라에 걸쳐 미얀마의 난민이 유입되고 있다. 미얀마에 난민이 발생하게 된 배경은 상당히 복잡하고 역사적이다. 미얀마는 불교도이면서 다수를 차지하는 버마족과 토착 소수민족 및 외국계 소수민족으로 구성된 연방국가로서 1948년 1월 영국으로부터 독 립했다. 미얀마가 독립국을 선포한 이래 국경지역에 있던 10 여개의 소수민족들이 정부로부 터 각각 독립을 주장하며 정부군과 무장투쟁에 돌입하였다. 소수민족들이 분리 독립을 요 구하는 이유는 미안마의 주류민족이자 불교도인 버마족의 소수민족 차별 정책에 반발하였 고 미얀마(버마족)중심의 군사정권의 압박이 심화되면서 식민통치시대보다 열악한 상황이라 는 인식이 팽배했기 때문이었다. 미얀마의 대표적인 소수민족으로는 로힝야족, 샨족, 카렌 족, 카친족, 친족 등이 있으며, 중국계와 인도계도 상당부분을 차지한다. 미얀마는 전통적으 로 소승불교 문화가 있지만, 카렌족, 카친족, 친족 등과 같은 소수민족들은 기독교를 수용 하였다(장준영, 2012).

미얀마 정부는 미얀마 내의 종족을 총 135 개로 분류하고 있는데 그 수에 비례하는 수많 은 반정부 조직들이 산재해 있기 때문에 십 수개의 반정부 조직과 평화 협상을 체결했다고 하더라도 여전히 많은 수의 조직이 반정부 무장투쟁을 벌이고 있어 사상자와 난민의 수가 지속적으로 발생하고 있다(장준영, 2012). 2017년부터 미얀마 서부 지역에서 미얀마 정부는 반군 토벌을 이유로 로힝야족에 대한 인종청소를 시작 했으며 카친 주를 포함한 국경 지역 의 소수민족 반군에 대한 공격과 민간인에 대한 폭력적 소탕을 강화했다(연합뉴스, 2018).

유엔난민기구(UNHCR: United Nations High Commissioner for Refugee)의하면 소수민족 중 가 장 큰 인구수를 가지고 있고 가장 정치적, 종교적 폭력을 당하고 있는 이슬람종교의 로힝 야족은 60 만 명 이상이 방글라데시로 피난하였다(정병선, 2017). 이 외에도 인근 국가인 태 국, 캄보디아 등으로도 피난하였다.

친족은 주로 말레이시아로 파난하였다. 친족은 본래 역사적으로 티베트에서 이주한 소수 민족으로서 대부분 기독교들로 구성되어 있다. 말레이시아에 등록 된 유엔 공식 난민 및 난민 지위 신청자는 약 150,662 명이다(UNHCR, 2017). 말레이시아에 등록 된 난민 중 약 89\%는 미얀마 출신으로 친족 외에도 로힝야족, 미얀마 무슬림인들, 라킨스족, 아라칸 족 등 의 소수민족도 포함되어 있다.

친족도 미얀마 정부군으로부터 학살, 강제 징집과 노동, 방화, 강간 등의 폭력을 당해왔 
으며 이를 피해 가난, 질병, 치료, 교육, 가족의 보호, 취업 등의 기회를 얻기 위해서 말레 이시아로 탈출하였다(허춘중, 2017). 말레이시아는 말레이인을 비롯해서 화교와 인도계 등 다양한 인종 및 민족적 배경을 가진 국가로서 소위 다문화에 대한 개방성을 갖고 있다(홍 석준, 2016). 따라서 말레시아는 친족을 비롯한 기독교 배경을 가진 미얀마 난민들이 선호 하는 국가 중의 하나가 되었다(Kaur, 2007). 그러나 말레이시아는 계속적인 난민의 유입으로 발생하는 사회적 어려움과 국민들의 거부감으로 인해 최근 들어 난민의 수용을 거부하고 유엔 난민 지위를 가진 난민에게조차 무차별적으로 신변의 위협을 가했다(Bartholomew, Gundel, \& Kantamneni, 2015). 즉 난민지위를 신청했지만 아직 신청이 받아들여지지 않은 사람들 소위 “자격 없는 이주자"에게는 구금과 매질, 추방 등 단속을 하고 있다(장복희, 2017). 최근 미얀마 정부는 로힝야족을 제외한 난민들을 미얀마로 돌려보내기로 결정했고 난민들이 본국으로 돌아갔을 때의 보복이나 위험에 직면할 것이라는 국제사회의 비난을 의식해 이들을 난민 아닌 불법체류자로 규정했다(연합뉴스, 2021).

탈출과정에서 아동들은 성인에 비해 취약한 상태에 있으며 이중, 삼중의 어려움을 겪을 가능성이 크다. 예를 들면, 피난과정에서 공격을 당해 부모나 다른 가족구성원이 사망하거 나 부상을 당하기도 하고 일행 중 누군가가 사망하거나 부상당하는 장면을 목격하기도 한 다. 보트피플의 경우에는 생존율이 낮으며 배 안에서의 폭력, 굶주림, 죽음 등을 경험한다 (Human Right Watch, 2013). 또한 아동은 발달특성상 성인과 다른 다양한 생물학적, 심리사 회적 욕구가 충족되어야 하지만 난민들이 살아가는 환경은 난민지위를 갖고 있는 경우조차 안정적이지 못한 신분으로 인해 취업의 제한, 불법 구금, 폭력, 착취 등의 사회적 불이익과 차별을 당한다(Davies \& Webb, 2000). 그 외에도 강제 이주, 이방인으로서 새로운 곳에 정착 해야 하는 어려움, 난민에 대한 부정적 인식을 경험한다.

이러한 상황과 경험은 아동들에게 다양한 심리적 어려움을 유발한다. 난민 아동들은 이 러한 낮선 환경에서 겪는 비탄, 외로움, 정체감, 상실 등의 정서적 문제로 인해 난민아동의 대부분 심리적 외상과 스트레스로 인한 불안, 우울, 심한 분노, 수면장애, 자살 사고, 기억 혼란, 주의력 결핍, 구토와 같은 신체화 증상을 보일 수 있다(Alayarian, 2007). 또한 심리적 외상은 '실제적이거나 위협적인 죽음 및 상해, 또는 개인의 신체적인 안녕을 위협하는 사건 을 본인이 직접 경험한 경우 뿐 아니라 타인에게 일어나는 것을 목격한 경우에도 발생한다 (American Psychiatric Association, 2000).

이러한 스트레스는 아동들에게 정서 및 행동문제를 일으킬 가능성을 높인다. 선행연구에 서도 난민아동의 상당수는 외상 후 스트레스 장애와 우울, 불안을 경험하며(Ehntholt 외, 2018; 송효진, 김소영, 이인선, 한지영, 2018), 문화적응스트레스, 학교적응 등의 어려움을 경 험한다(Beman, 2011; Kimayer 외, 2011). 특히 본국을 떠나 난민 신청국에 도달하기까지의 폭 력과 생명의 위협 등 여러 취약한 상황에 노출되는 경우 더 심각한 신체적, 정서적 트라우 
Journal of Symbols \& Sandplay Therapy, Vol.12 No.1.

마 증상을 보일 가능성이 높다(송효진, 김소영, 이인선, 한지영, 2018). 낮선 환경으로의 이 주 자체도 발달의 전환기에 있는 아동에게 정신건강의 문제 발생 가능성을 높인다(Karlsen \& Nzaroo, 2002; Bengi-Arslanetal. 1997). 아동들은 부모가 재난이나 폭력 이후 가족의 갈등 과 같은 삶에 대처하는 방식에 의해서도 영향을 받는다(Deeva \& Rapee, 2015; GranthamMcGregor et al.. 2007). 또한 사건 후 양육자의 심리적 상태와 아동의 외상 후 증상, 행동문 제, 공격성이 밀접하게 연관되어 있다는 연구결과들도 있다(Chemtob, Nomura, \& Abramovitz, 2008; Chemtob et al., 2010; Scheeringa \& Zeanah, 2008).

외상경험을 언어로 표현하거나 외상경험의 부정적 경험을 조절할 수 있는 자아발달이 이 루어진 성인과 달리 아동들은 제한된 언어 발달과 자아발달로 인해 트라우마나 스트레스를 조절하는 능력이 부족하다(최남희, 2006). 따라서 아동에 대한 심리치료적 접근은 성인과는 다른 측면에서 이루어져야 한다. 모래놀이치료는 아동이든 성인이든 내담자가 자신과 경험 을 자유롭게 표현할 수 있는 안전하고 보호적인 공간을 제공함으로써 인간 정신 안에 있는 치유적 잠재성이 발현되는 것을 가치 있게 여기는 심리치료 접근이다(Kalff, 1980). 또한 모 래, 상자, 물, 피겨 등 언어 없이도 자신을 투사하고 표현할 수 있는 상징을 제공함으로써 언어로 표현하는 것에 어려움이 있거나 심각한 외상이나 원형적이고 무의식적인 치유 잠재 력처럼 언어로 접근하기 어려운 경험을 표현할 수 있게 한다(장미경, 2017a; Gil, 2006; Malchio, 1997, 2008). 모래놀이치료가 분석심리학에 이론적 근거를 두고 있기 때문에 모래놀 이든 미술, 음악이든 그 통로가 제공된다면 무의식적 경험 또한 표현될 수 있다고 가정한 다(Rowland, 1999). 외상경험을 언어로 표현하는 겻이 오히려 외상의 부정적 영향이 더 지속 되게 할 수 있다는 주장도 있다(Kawai, 2015).

모래놀이치료에서 말하는 상징은 원형에서 기원하며 원형은 이미지 형태로써 원형에너지 를 배열 시키고, 이 이미지는 개인적·문화적 - 인종적 - 종교적으로 관련 있는 상징에 투사 된다(장미경, 2017a; Jung1984/2002). 상징은 자발적으로 발생하며, 치유적이고 에너지-변화 적인 힘을 갖고 있다. 그 힘은 의식과 무의식을 표상하는 상징을 매개하는 기능을 하는데 언어로는 다 이해 할 수 없는 관점을 표현한 것이다(장미경, 2017a, Jung 1984/2002). 또한 emotions와 actions에 대한 비언어적 표현은 언어표현 보다 더 즉각적인 효과를 갖고 있으며 (Lacroix et al., 2007; Cook 외., 2005; Malchiodi, 2003) 감각을 사용하는 개입을 통해 활성화 될 수 있다(Steele, 2006). 이러한 부분에 있어서 모래놀이치료의 접근은 난민 아동의 내적, 문화적자원 등을 고려하여 개입하는 심리치료접근이라 할 수 있으며, 난민 아동들이 외상 을 극복하고 외상경험을 내재화하거나 외현화한 갈등을 해결하고 숙련감과 통제감을 발달 시켜 문제 상황을 해결해 나갈 수 있도록 도울 수 있을 것이다(Kalff, 2003). Jung은 "무의식 의 예기치 못한 위험한 범람으로부터 자신을 방어하려는 오직 하나의 목적으로 실시되는 마술적 의례가 수없이 많다"다고 하였으며(Jung, 1984/2008) 외상 생존자들에게는 이러한 
표 1.

\begin{tabular}{|c|c|c|c|c|}
\hline $\begin{array}{l}\text { 연구 } \\
\text { 참여자 }\end{array}$ & 성별 & 연령 & $\begin{array}{l}\text { CRIES-13 } \\
\text { 점수 }\end{array}$ & 연구참여자 특성 및 역사 \\
\hline 아동A & 여 & 11 & 26 & $\begin{array}{l}\text { 아버지 및 남동생과 살고 있으며 3살 때 말레이시아로 탈출하였 } \\
\text { 고 탈출하는 과정에서 어머니가 사망함. }\end{array}$ \\
\hline 아동B & 남 & 15 & 39 & $\begin{array}{l}\text { 3년 전 말레이시아로 탈출함. 탈출 과정에서 미얀마의 폭력적인 } \\
\text { 탄압으로 가족 모두 사망하였으며 가족이 죽어가는 모습을 목격 } \\
\text { 하였음. 홀로정글에서 생활한 적이 있음. }\end{array}$ \\
\hline 아동C & 남 & 11 & 34 & $\begin{array}{l}\text { 말레이시아로 탈출하는 과정에서 태국군인에게 쫒기면서 가족을 } \\
\text { 모두 사망하였고 현재 정글에서 주변사람들의 도움을 받아 혼자 } \\
\text { 생활하면서 난민학교에 다니고 있음. }\end{array}$ \\
\hline 아동D & 남 & 11 & 19 & $\begin{array}{l}\text { 미얀마에서 집이 공격을 받은 후 가족과 함께 며칠씩 걸어서 말 } \\
\text { 레이시아로 탈출함. }\end{array}$ \\
\hline 아동E & 남 & 12 & 37 & $\begin{array}{l}\text { 4세 때 말레이시아로 부모와 함께 탈출하였으며 탈출 도중 아버 } \\
\text { 지의 허리부상으로 일을 할 수 없는 상태가 되었으며 말레시아 } \\
\text { 에서 2년째 생활고를 격고 있음. 어머니가 생계를 유지했으나 아 } \\
\text { 버지와의 갈등과 생활고로 돈을 벌어온다며 외할머니가 있는 미 } \\
\text { 얀마로 돌아감. }\end{array}$ \\
\hline
\end{tabular}

'마술적 의례'가 필요하며 모래놀이치료는 그러한 기회를 제공할 수 있을 것이다.

본 연구는 내전과 핍박을 피해 말레이시아로 탈출하는 과정에 폭력과 고통을 당했으며, 가장 소중한 가족의 사망이나 부상을 직접 경험하거나 목격하였고 새로운 곳에서 차별과 미얀마로 되돌려질지도 모르는 불안과 두려움, 그리고 차별 속에서 살고 있는 말레이시아 거주 미얀마 친족난민 아동들의 모래놀이치료에 나타난 상징 및 주제를 분석하였다.

\section{ㅍ. 연구방법}

\section{1. 연구 참여자}

본 연구의 참여자는 말레이시아의 쿠알라룸푸르에 거주하는 미얀마 난민아동 중 친족 아 동들이다. 이 아동들은 쿠알라룸푸르 소재 유엔난민기구에서 운영하는 말레이시아의 국제 난민학교에 재학중이다. 이 학교 대상 아동으로 심리치료 개입을 위해 이루어진 심리검사 결과에서 위험군 이상의 점수에 속하는 아동들 중 아동과 보호자 모두 연구 참여에 동의 
Journal of Symbols \& Sandplay Therapy, Vol.12 No.1.

한 만 8-15세 아동 약 5명이 연구참여자로 선정되었다. 이들은 모두 PTSD 판별을 위한 CRIES-13에서 PTSD 진단가능성이 높은 19점 이상에 해당했다. 연구 참여아동들은 미얀마로 부터 끈임없는 폭력과 위협, 가족과 지인들의 부상이나 사망을 경험하였고 육로를 통해 부 모를 비롯한 보호자와 함께 수 백 킬로를 걸어 말레이시아로 탈출하였다. 탈출과정에서도 다양한 폭력과 공격을 겪었거나 사망 또는 부상을 목격하였다. 말레이시아에서도 난민지위 를 받은 참여자는 소수였으며 난민지위 유무와 상관없이 언제 발생할지 모르는 추방 그리 고 제한적인 경제적 수입, 열악한 주거환경, 부모들의 질병, 갈등, 부모의 학대, 사회적 차 별 등을 경험하고 있었다. 그로 인해 가정과 난민학교로만 활동공간이 제한되었고 이들의 부모들은 난민을 받아들이거나 난민에 호의적인 국가로 갈 수 있는 기회를 찾고 있었다.

연구 참여자의 인구사회학적 사항은 표 1 과 같다.

\section{2. 연구절차}

심리검사 결과에서 PTSD 위험군 점수에 속하는 아동들에게 모래놀이치료를 제공하기 위 해 그들의 보호자들에게 구두, 전화를 통해 동의를 구하였다. 이후 보호자의 동의와 연구 및 촬영에 대해 서면동의를 받은 5명을 최종 선정하여 개별모래놀이치료를 제공하였다. 개 별모래놀이치료는 2018년 7월 4주 동안 회기별 50분씩 총 5회기가 이루어졌다. 장소는 국 제난민학교에서 방과 후 시간에 빈 교실을 활용하여 모래놀이치료 세팅을 한 곳이었다. 모 래놀이치료는 Dora Kalff의 접근 방식으로 '자유롭고 보호받는 공간' (Kalff, 1980)을 제공하 는 접근의 개입으로 이루어졌다.

연구참여자들의 외상 후 스트레스 평가를 위해 사전에 아동용 사건 충격척도(The Children's Revised Impact of Event Scale: CRIES-13)를 실시하였다. CRIES-13는 총 13문항으로 구성된 4점 Likert 척도로 $(0=$ not at all; $1=$ rarely; $3=$ sometimes; and $5=$ often $) 3$ 가지 하위 요인인 침습, 회피, 과각성으로 구성되어 있다. 총점은 65 점으로 침습과 회피의 경우 20 점 이상, 과각성 의 경우 25 점 이상, 총점이 30점 이상 일 경우 PTSD로 임상적 진단이 가능하였다(Deeba, F., Rapee, R. M., \& Prvan T., 2014). 실시했던 외상 후 스트레스 척도 결과 연구참여자들은 진 단 가능성이 높은 19 점 이상인 아동들로 PTSD 진단이 가능한 수준(CRIES-13 Total $\geqq 30$ )이 었다. 연구참여자의 언어적 특성을 고려하여 언어적 어려움을 최소화 하기위해 영어와 미 얀마어의 척도를 사용하였다. 각 회기 동안 연구 참여자들의 모래상자, 언어적 보고, 비언 어적인 행동 등을 분석하기 위해 사전에 연구에 대한 충분한 설명과 함께 서면동의를 얻은 후 기록, 녹화, 녹음이 이루어졌다. 
김혜영· 조은진 · 장미경 / 말레이시아 거주 미얀마 친족난민 아동의 모래놀이치료 상징 및 주제연구

\section{3. 연구방법}

본 연구는 말레이시아 거주 미얀마 친족난민아동의 모래놀이치료 과정에서 나타난 상징 및 주제의 특성을 이해하기 위해 Creswell(2007)의 질적사례 연구방법을 사용하였다. 질적사 례 연구에서 자료 분석은 사례에 대해 총체적인 분석을 할 수도 있고 사례의 특정한 측면 에 대한 깊이 있는 분석을 할 수도 있다. 이는 각 사례의 주제와 각 사례에 대한 자세한 기술, 사례에 따른 주제별 분석으로 이루어지고 사례의 의미에 대한 주장이나 해석을 함께 제시할 수 있다(Creswell, 2007). 그러한 의미에서 질적사례 연구는 미얀마 친족 난민아동의 모래놀이치료에서 나타나는 상징 및 주제를 이해하고 그러한 상징 및 주제가 나타나는 맥 락을 규명할 때 유용할 것이라고 할 수 있다.

\section{4. 자료처리}

본 연구의 자료는 자료수집, 자료의 의미 파악, 분석하기, 기술 및 해석, 시각화를 통한 보고의 분석 순으로 처리가 진행되었다. 자료 수집은 총 5회의 개별 모래놀이치료 세션에 서 모래상자 사진, 동영상 녹화물, 대화기록, 관찰내용 기록 등을 포함 하는 심층적 자료 수집으로 이루어졌다. 자료처리단계에서는 연구참여자 전체의 모래놀이치료 회기 내용의 동영상, 대화 기록물을 모두를 포함하여 전사하고 이를 번역하여 원 자료화 하였다. 분석하 기 단계에서는 연구자가 모래상자 사진과 회기 내용에서 언어 및 비언어적 표현을 반복해 서 보며 나타난 공통된 주제와 상징들을 세밀히 분석했다. 이것을 바탕으로 공통적으로 나 타난 상징과 주제들을 범주화하고 그것을 시각화하여 표로 제시하였다. 이 과정에서 연구 의 엄격성을 위해 박사과정 모래놀이치료사 2 인 및 모래놀이치료 수퍼바이저이자 교수인 또 다른 전문가 한 명이 참여하였다.

\section{5. 연구의 엄격성}

본 연구는 질적 연구의 엄격성을 위한 연구 설계의 질을 평가하는 기준으로 Lincoln과 Guba(1985)가 제시한 신뢰성, 적합성, 일관성, 중립성의 기준과 사례연구에 적용되는 기준을 준용하고자 다음과 같이 노력하였다. 본 연구에서 Lincoln과 Guba(1985)가 제시한 신뢰성, 적 합성, 일관성, 중립성의 4 가지 평가 기준을 본 연구에서 적용한 검증 방법은 다음과 같다.

첫째, 환경으로 진입하는 단계에서 다른 질적 연구와 마찬가지로 연구자의 상황과 참여 자와의 깊은 공감을 형성하고 연구 참여자가 적극적 참여를 통해 현상을 있는 그대로 볼 수 있는 환경을 만들어 나가는 과정을 확보하기 위해 노력 하였다. 연구 참여자의 반응과 
Journal of Symbols \& Sandplay Therapy, Vol.12 No.1.

연구자와 연구대상의 치료과정에서 개별모래놀이치료를 시작하기 전 연구 참여자 담당교사 와 면담을 통해 연구 참여자의 배경정보, 주호소등 개인사에 대해 탐색하였다. 연구 과정에 서는 더욱이 모래놀이치료가 심리치료의 라포형성을 중요시하는 접근이므로 연구와 심리치 료의 효과성을 위해 친밀함형성과 이를 통한 신뢰감 형성을 위해 노력하였다. 또한 이어지 는 세션에서 연구참여자의 상황을 더 잘 이해하기 위해 매 회기 중 연구 참여자의 언어적 또는 비언어적 표현과 모래장면에 대한 언급을 기록함과 동시에 동영상과 모래상자 사진을 촬영하고 연구 참여자의 행동관찰과 모래장면을 촬영 및 녹화 수집하여 내적타당도를 확보 하고자 하였다.

둘째, 연구 참여자의 모래놀이치료 과정에서 연구참여자의 내적 상황과 얼마나 잘 연결 되는가, 혹은 연구의 주제를 얼마나 효과적으로 전달하고 있는가를 판단하기 위해 연구자 는 연구 참여자가 치료과정에서 편안하고 자유롭게 이야기 할 수 있도록 개인들의 경험에 대한 감정과 상황들을 충분히 모래상자에 표현하도록 하였다.

셋째, 연구의 일관성 확보를 위해 연구참여자들의 다양한 경험 진술 내용들이 비슷한 결 론에 도달하는지 또는 특이성이 존재한다면 그것이 과정상의 특이성인지 아니면 다른 연구 참여자들과 완전히 다른 특이성인지 그리고 특이성이 존재한다면 특이성이 원인을 이해하 고자 노력하였다. 자료수집, 분석, 결과도출에 이르기까지 모래놀이치료자이자 동료인 박사 과정생 2 명 및 모래놀이치료와 모래놀이치료 연구경험이 풍부한 지도교수와 분석된 상징과 주제에 대한 객관적이고 일관성 있는 분석을 위한 상호주관성을 확보하기 위해 노력하였 다. 또한 연구 절차와 분석내용, 결과에 이르는 과정상의 체계성, 엄밀성을 위해 최대한 상 세히 기록하였다.

넷째, 연구자의 영향력을 최소화하기 위해 연구자는 연구참여자들에게 공감적이면서도 그들의 경험기술 및 모래놀이치료 경험하기 과정을 수용하기 노력하였다. 공감은 질적 연 구의 참여자 뿐 아니라 및 심리치료의 내담자들이 치료자의 방해를 받지 않으면서 자신의 경험과 감정을 진솔하게 표현할 수 있는 안전하고 신뢰로운 관계형성의 방법이라고 할 수 있다(장미경, 2017b).

\section{6. 윤리적 고려사항}

본 연구는 남서울대학교 연구 생명 윤리적 심의를(IRB 1041479-HR- 201804-005)거친 후 진행하였고, 참여자들의 윤리적 고려를 위해 면담에 앞서 연구 목적과 방법에 관한 내용을 설명하였으며 면담 내용을 녹음하고 촬영하였으며, 녹음과 촬영된 내용은 연구 목적 이외 에는 사용하지 않으며 면담 과정에서 참여자들을 관찰하고 녹음된 내용이 본 연구에 인용 될 수 있으나 익명을 보장하며 참여자의 신원이 드러날 우려가 있는 내용은 인용되지 않을 
것임을 서면으로 제공하여 설명하고 연구에 대한 사전 동의서를 받았다. 면담 시 면담 시 간대와 장소는 참여자들의 정신적, 신체적 불편함으로부터 보호하기 위해 참여자들이 선정 하고 동의 하였고 면담 도중 언제라도 중단하고 싶은 경우 거절할 수 있음을 알렸다. 또한 연구가 종료된 후 모든 자료는 폐기될 것임을 설명 하였으며, 참여자의 상담 요청 시 도움 을 제공할 것을 약속하였다. 또한 최종 연구 보고서에는 참여자의 개인정보와 민감 정보에 대해서는 일체문서화하지 않고 누락하여 신상이 추측되거나 공개되지 않도록 보호 하였으 며, 연구 종료 후 노트북이나 저장된 개인 신상 자료와 종이 문서 자료는 일체 폐기하였다.

\section{III. 연구결과}

\section{1. 사례에 대한 기술}

\section{1) 아동A}

$\mathrm{A}$ 아동은 아버지 및 남동생들과 함께 살고 있으며, 어머니는 아동A가 3살 때 말레이시아 로 탈출하는 도중에 사망하였다. 아동은 국제난민학교 내의 학생 자치활동 중에서 설거지 담당을 하고 있었다. 아동용 사전충격척도 결과(CRIES-13 총점 26점)에서 트라우마로 인해 과거의 사건이 현재 순간적으로 생생하게 떠오르거나 외상을 완전하게 재 경험할 수 있는 높은 수준이었다. 아동A는 11세 여자아동으로 연구자와 눈을 마주치면 바로 다른 곳으로 보면서 눈길을 피 하는 듯 보였다.

아동A는 첫 모래장면에서 쑥스러운 모습으로 시작하였다. 피겨를 선택하며 가져다 놓을 때도 조심스럽게 하는 듯 하나 긴장된 모습으로도 보였다. 연구자를 아동은 모래장면에 엄 마, 아빠, 남동생, 아기 피겨를 교회 앞에 놓았다. “가족들이 매주 일요일에 모두 교회 앞에 모여서 신에게 기도를 해요”라고 이야기 한다. 집을 놓은 후 그 앞에 자동차를 놓고서는 "이것은 우리 아빠 자동차이고 여기는 우리 집 이에요. 그런데 이건 제 희망이고 진짜가 아니어서 슬프다.” 라고 이야기 했다. 2 3회기 모래장면에서 아동은 엄마, 아빠, 남동생, 아 기 피겨를 선택하여 놓은 후 가족이라고 한다. "아빠는 일하러 가고 엄마는 요리하고 동생 들은 그냥 놀고 있고 있는 것 같아요." 이후에 모래장면에 피겨들을 다시 재배치한 뒤 “가 족 모두가 함께 식사 한다.”라고 이야기 했다. 4 5회기 모래장면에서도 아동이 식탁위에 음식을 차린 후 가족과 함께 음식 먹는 놀이와 집 안 소파에서 휴식을 하다 식탁에서 침대 로 이동하여 누워서 쉬는 놀이를 하였다. 아빠를 이동하면서 “아빠는 일하는 중 이다.", “동 생들은 노는 중” 이라고 이야기 한다. 아기를 침대에 눕히고, 엄마는 음식 먹은 것을 정리 한 후 청소기를 들고 청소하는 모습을 보인다. 잠시 후 엄마를 의자에 앉힌다. 아빠가 나갔 
Journal of Symbols \& Sandplay Therapy, Vol.12 No.1.

다가 돌아온 후 모든 가족이 식탁에 앉고 엄마는 음식을 차려 식탁에 올려놓는다.

\section{2) 아동B}

아동B는 15 세 남자 아동으로 처음 만났을 때 말없이 눈동자를 이리저리 굴리며 불안한 모습이었고 긴장수준이 높아 보였다. 아동 $\mathrm{B}$ 는 3년 전 말레이시아로 탈출하는 과정에서 미 얀마의 폭력적인 탄압으로 가족을 모두 잃고 가족이 죽어가는 모습을 직접 목격하였고 고 아가 되어 정글에서 생활하였다. 현재는 주변에 한 가정에서 아동을 돌봐주고 있는 상태이 며, 학교에 입학한지 얼마 안 되어 학업적인 부분이 많이 부족하다는 현지 선생님의 보고 가 있었다. 아동용 사전충격척도 결과(CRIES-13 총점 39점) 높은 점수로 PTSD의 임상적 진 단이 가능한 수준이었다. 아동B는 미얀마를 탈출해서 3 년이 지났음에도 불구하고 외상경험 이 그대로 가지고 있다는 것을 알 수 있다.

아동 $\mathrm{B}$ 는 첫 회기에 말없이 눈동자를 이리저리 굴리며 한 참을 가만히 있다가 모래놀이를 시작하였다. 1 회기 모래장면에서는 나무를 놓고 울타리 안에 나무, 동물, 곤충들을 놓으며 “이 곳이 동물원 이다"라고 했다. 다른 울타리 안에는 교회, 수도자, 아기예수, 기도하는 사 람을 올려놓았다. 이 곳은 교회이고 사람들이 신에게 “천국 가기를 기도한다. 행복하고 행 복하다.” 라고 이야기 했다. 2 3회기 모래장면에서는 전 시간 보다 좀 편한 모습으로 모래 장면을 만들기 시작했다. 교회, 나무, 울타리, 아기예수, 테이블과 의자, 작은 연못 등을 가 져다 놓으면서 “죄인을 용서해달라고 교회에서 기도하는 것”이라고 했다. 교회 앞쪽에 나무 와 울타리로 길을 만들었다. 4 5회기 모래장면에서는 교회와 나무를 중심에 놓고 그 주위 를 울타리로 쳤다. 교회 옆에는 예수, 십자가, 목사, 어린아이를 놓으면서 "이곳은 교회이고 마을이다”라고 했다. “마을사람들은 집 앞 벤츠에 앉아 쉬면서 서로 이런저런 이야기를 나 누고 있는 것이다".라고 하였다.

\section{3) 아동C}

아동C는 11세 남자 아동으로 왜소한 체구를 가지고 있었으며, 시선을 마주치지 않고, 긴 장되고 위축되어 있었다. 말레이시아를 탈출하는 과정에서 군인에게 쫓기고 가족을 모두 잃어 버리고 고아가 되어 정글에서 생활하고 있었다. 현재는 주위사람들의 도움을 받아 지 내고 있었다. 아동용 사전충격척도 결과(CRIES-13 총점 34점)높은 점수로 30점 이상은 $\mathrm{PTSD}$ 의 임상적 진단이 가능한 수준이었다.

첫 회기에서 아동C는 시선을 마주치지 않고 모래장면에만 시선을 고정하였다. 한참 후 모 래장면을 만들기 시작한다. 두 팀의 군인들이 전쟁을 하고 있다. 전쟁 후 회색군인들이 모 두 죽고 승리한 초록 군인이 새를 잡아먹는다. 초록 군인은 불을 가지고 있고 회색 군인은 큰 총을 가지고 있다. "군인들은 집을 차지하기 위해서 싸운다."라고 한다. 초록 군인들은 
싸움에서 지고 나면 숲이나 산으로 가게 된다. "회색 팀이 지고 초록색 팀은 이긴다. 왜냐 하면 초록 팀이 강하고 크기 때문이다. 회색 팀은 져서 모두 죽고 그곳을 차지하게 될 것 이다.” 라고 하였다. 2 회기 아동C는 잠깐 머뭇하더니 모래장면을 만들기 시작한다. 피겨를 선택하면서 아동은 인상을 찌푸리더니 눈을 비빈다. 비행기와 구급차 피겨를 가져다 놓고 경찰차와 자동차를 가지고 와 부딪치며 왔다 갔다 하고 길도 만든다. 피겨를 책상 옆으로 빼놓고 모래상자에 모래를 다듬는다. 공룡 피겨를 가지고 와서는 공룡에게 모래뿌리더니 공룡들끼리 싸우기 시작 한다. 또 아주 큰 뱀을 가지고 와서 뱀끼리 똬리를 틀고 물고 다 시 익룡이 뱀을 들고 나르다가 떨어뜨리고 다시 악어와 공룡이 싸우는 장면을 표현한다. 다시 책상옆으로 피겨를 빼놓은 후 초록색군인 피겨와 군용차를 한꺼번에 가지고와서 가운 데에 놓는다. 3 4회기 모래장면에서는 아동C는 피겨를 바로 선택하러 가는 적극적인 모 습으로 참여하였다. 집에는 가족이 살고 있고 형, 자신, 여동생, 아빠, 엄마가 함께 살고 있 다. 함께 살고 있는 가족들의 표정은 형은 여동생을 놀리고 있고 여동생은 울고 있고 자신 은 웃고 있다. 그 모습에 아빠는 화가 많이 났다. 집이 불이 나서 많은 사람들이 불을 끄고 있고 물을 필요로 하고 있다고 하였다. 아기가 불을 내서 집에 불이 났다. 사람들은 헬리콥 터를 타고 다시 돌아온다. 모두 집에 불을 끄기 위해 도와주고 있다. 마지막 회기 모래장면 에서는 아기가 자동차를 타고 다른 나라로 가고 있다고 하였다. "아기 혼자만 간다.”고 하 였다. 아기와 같이 가는 사람은 없고 혼자만 길을 가고 있다고 하였다. 아기의 형은 건너편 에 있다고 하였다.

\section{4) 아동D}

아동 $\mathrm{D}$ 는 11 세 남자아동으로 또래보다 키가 작고 왜소하였다. 긴장하면 눈을 깜박거리는 행동을 보였고 시선을 피하며 혼잣말을 많이 하였다. 미얀마폭력사태로 집이 공격을 받은 후 가족과 함께 며칠 씩 걸어서 말레이시아로 탈출하였다. 아동용 사전충격척도 결과 (CRIES-13 총점 19점)로 17점이상은 PTSD로 진단받을 가능성이 높다.

아동D는 첫 회기 모래장면에서는 공사하는 사람들과 군인들은 일하고 있고 아기들은 놀고 있다. 교회 옆의 집은 소방관들의 집이다. 공사하는 사람들은 버스를 타고 집으로 가고 있 다. 공사하는 사람들은 교회 옆에 있는 집에 같이 살고 있다. 인디언 집은 바다음식을 파는 레스토랑이다. 2 회기 모래장면에서 오른쪽 위를 가리키며 "교회에서 일을 하는 곳이고 비 행기가 있는 곳은 공항이다.” 왼쪽 위는 동물원이고 중간에 있는 건물은 집이고 그 옆에 있는 사람은 경찰이라 한다. 경찰은 집에 살고 있다. 노란버스는 공사하는 사람들의 차이 다. 공항에서 비행기를 타면 다른 나라로 간다. 3회기 모래장면에서는 나무가 있는 곳은 바 다이고 하얀 꽃이 있는 곳은 집이다. "아래쪽에 있는 집은 잃어버린 집이고, 크레인 옆에 있는 집은 새 집이다. 잃어버린 집은 레스토랑이다 레스토랑 안에는 맛있는 바다음식이 있 
Journal of Symbols \& Sandplay Therapy, Vol.12 No.1.

다. 그 곳에 있는 바다음식을 먹고 있다." 라고 이야기했다.

4 5회기 모래장면에서는 "이곳은 섬이다." 비행기들이 있으며 집에는 군인이 살고 있다. 초록색은 군인이고 회색은 여행자들이다. 초록색군인 보스와 회색의 보스는 친구여서 이들 은 싸우지 않는다. 초록색 군인들이 다른 쪽 사람들에게 알려주려고 가르쳐 준다. 이 사람 들은 정글로 집을 지으려고 가고 있다. 정글에서는 싸움 놀이는 하지 않는다. 초록색군인들 은 정글에 살기를 원한다. "비행기를 타고 미얀마로 날아가고 싶다, 그러면 행복할 것 같 다." 라고 하였다.

\section{5) 아동E}

아동E는 12 세의 남아 아동으로 또래보다 큰 키를 가졌으며, 두 손으로 자주 모아 잡는 모습과 얼굴을 상담자 앞으로 가까이 하는 모습을 볼 수 있었다. 아동E는 4살 때 말레이시 아로 아버지와 어머니와 함께 넘어왔으며 탈출과정에서 아버지는 허리부상으로 일을 할 수 없게 되었다. 수입이 없어 지속적인 생활고를 겪어왔으며 그 후 어머니는 생활고를 피하기 위해 돈을 벌어 온다며 외할머니가 있는 미얀마로 돌아가서 아직 까지 돌아오지 않고 있 다. 아동용 사전충격척도 결과(CRIES-13 Total $=37$ 점)높은 점수로 30 점 이상일 경우 $\mathrm{PTSD}$ 의 임상적 진단이 가능한 수준이었다.

아동E의 첫 회기 모래 장면은 "아주 큰 뱀이 사람들을 먹는다. 큰 뱀은 위험하고 무섭다. 울타리를 쳐서 사람들을 보호해야 한다.” 그러나 예수가 나타나서 큰 뱀은 뱀의 집으로 돌 아갔다. 그러자 사람들은 행복해졌다. 사람들은 예수님께 성체를 받아먹으려고 줄을 서고 그것을 받아서 먹고 기도한다. 사람들은 노래를 부르며 예수를 찬양한다. 사람들은 모두 교 회에 와서 예수를 만나기 원하고 그를 찬양하고 찬양한다.

2회기 모래장면에서는 이집트 사람과 아메리카 군인이 대극을 이루어 전쟁을 하고 있다. 아메리카 군인들이 땅속에 돌을 가지고 있는데 그 돌은 중요하다고 하다. 그런데 아메리카 군인들이 자고 있을 때 다른 나라 군인들이 그 돌을 가져가려고 한다. 마지막에는 아메리 카 군인이 승리한다. 3 회기 모래장면에서는 전사들이 전쟁을 하고 있다. 인디언이 구슬을 한 텐트 안에 넣는다. 인디언들이 잠이 든다. 다른 팀이 텐트 안에 구슬 한 개를 가져간다. 인디언이 싸워서 이겨서 구슬을 모두 되찾아가지고 온다. 그 구슬은 하늘에서 내려 준 것 이다. 구슬은 우리의 심장과도 같은 것이다. 4 회기 모래장면에서는 아동의 목소리가 커지고 표정도 밝아졌다. 새벽 4시에 배가 아파서 일어나서 아침을 먹지 못했다. 학교는 걸어서 왔다고 이야기 한다. 모래장면에서는 전사들이 전쟁을 한다. 보물을 중심으로 나무를 둘러 싸고 전사들이 지킨다. 천을 두룬 사탄이 하늘을 한 바퀴 날면서 돌자 공포에 휩싸인다. 팀 전사들이 모두 전멸한다. 나비요정이 손짓을 하자 전사들이 살아난다. 5 회기 모래장면 에서는 “나의 집과 우리가족이다, 우리 가족은 행복하다." 나의 동생은 5살이고 여기 난민 
학교에 다닌다. 아빠는 허리가 아파서 일을 못하고 집에서 음식을 만드신다. 아빠가 허리 가 아파서 내가 동생도 돌봐야 해서 힘들다. 나는 커서 의사가 되어서 아빠를 고쳐 주고 싶다. 엄마는 미얀마에 외할머니 댁에 계신다. 나도 “미얀마로 돌아가고 싶다 ”라고 이야 기 하였다.

\section{2. 사례 내 분석결과}

5 명의 아동들의 모래놀이치료 상징과 주제를 분석하기 각 사례 별 전체를 통합적으로 분 석한 결과 5 가지의 공통된 상징 및 주제를 발견할 수 있었다. 상징 및 주제 분석의 결과는 표 2와 같이 '두려움/공포 그리고 이에 대한 마음의 저항', '보호와 돌봄', '신의 존재와 죄 책감, '일상에 대한 회복의 노력, '평범한 삶에 대한 희망을 버리지 않음'의 주제였다. 분 석된 결과는 도출된 주제와 관련된 참여자 언어표현 및 놀이행동 중 일부를 발췌하여 제시 하고 관련된 연구자의 분석을 포함하였다. 각 주제와의 연관성을 잘 들어내기 위해 필요시 언어표현 인용 중간 중간에 표시하였다. 추가 설명이 필요한 경우(괄호 치기)로 제시하였다. 또한 이 주제를 대표적으로 잘 드러낸다고 판단되는 상징을 표에 요약 제시하였으며 모래 상자 사진을 결과 제시 부분에 언어표현 인용과 함께 제시하였다.

표 2. 미얀마 친족 난민아동의 모래놀이치료 상징 및 주제

\begin{tabular}{cc}
\hline $\begin{array}{c}\text { 공통된 주제 } \\
\begin{array}{c}\text { 두려움/공포 } \\
\text { 그리고 이에 대한 } \\
\text { 마음의 저항 }\end{array}\end{array}$ & - 전쟁하는 두 팀, 신화/괴물, 집에서 불이남, 큰 뱀의 공격 \\
\hline 보호와 돌봄 & - 안전한 공간(교회), 예수나 성모마리아, 아기예수, 십자가, 목사, 수도자 \\
\hline 신의 존재와 죄책감 & $\begin{array}{c}\text { - 교회, 영적 피겨(예수, 성모마리아) 성체를 받아먹는 성찬예식, 신에게 기도 } \\
\text { 하는 모습 }\end{array}$ \\
\hline 일상에 대한 & - 새로운 집, 정돈된 건축물, 울타리, 삶의 터전에서 원래대로 회복 하려는 \\
회복의 노력 & 것 \\
\hline $\begin{array}{c}\text { 평범한 삶에 대한 } \\
\text { 희망을 버리지 않음 }\end{array}$ & - 가족과 함께 사는 집과 그 알에에는 없는 알족 항적인 생활 하는 것들..... \\
\hline
\end{tabular}

\section{1) 두려움/공포 그리고 이에 대한 마음의 저항}

미얀마 난민 아동들은 미얀마에서 말레이시아로 탈출과정에서 무자비한 학살과 폭력을 직접 경험하였으며 고국을 떠난 후에도 무방비한 상태에서 인간으로서의 누려야 할 기본권 
Journal of Symbols \& Sandplay Therapy, Vol.12 No.1.

리나 미래의 안정을 보장받지 못한 채 소외와 차별, 가난과 불안, 고립감속에서 자신의 삶 에 혼란을 겪고 있다. 그것의 결과로 난민 아동들은 자신들의 삶의 터전이 불안정하며 강 제 추방 등 언제 파괴당할지 모른다는 불안감과 두려움, 이를 증명하는 유튜브 등을 통한 동포들의 죽음 소식 속에서의 삶을 지속하고 있다. 이런 두려움, 공포, 불안은 모래놀이치 료 과정에서 여러 가지 방식으로 드러났다. 불을 무기로 가지고 사용하고 있는 사람들과 총을 무기로 사용하고 있는 군인들의 전쟁, 사람을 잡아먹는 큰 뱀, 사악한 군인들이 착한 요정과 싸우는 장면, 새로운 다른 정체성을 대표하는 군인들의 전쟁 모습이 공통적으로 모 래장면에서 나타났다. 현실에서 이들이 속한 소수민족은 상대적으로 우월한 무기와 명수를 가진 미얀마 정부군에 곡갱이, 나무스틱, 불을 가지고 대항했고 그 결과는 말할 필요도 없 는 것이었다. 때문에 아동들은 사실적으로 이런 전쟁을 표현하기도 했지만 아동들은 자신 이 속한 소수민족이 미얀마 정부군처럼 힘을 가지고 대항했으면 하는 즉 현재의 두려움과 공포를 제거해주었으면 하는 바램을 표현하기도 했다. 이는 현실이 아닌 바램이지만 심리 적으로 원형적 공포를 야기하여 심리적 붕괴를 가져올 수 있는 극단적인 위협으로부터 자 신을 방어하는 심리적, 무의식적 노력이라고도 할 수 있을 것이다(장미경, 2017a).

아동 $\mathrm{E}$ 는 모래놀이치료 1 회기에서 "아주 큰 뱀이 사람들을 먹는다. 큰 뱀은 위험하고 무 섭다.”라고 표현하였다. 그 외에 공룡이나 뱀이 서로 공격하는 장면도 나타났다. 이는 공격 성을 상징한다고 볼 수 있는데, 이들이 보여 주는 공룡, 뱀, 맹수, 괴물 등이 침입으로 나타 나는 모래장면 과정은 감당하기 어렵고 설명하기 어려운 불안의 감정을 일으키는 자극을 의식적, 의도적으로 조절하기 위한 아이들의 두뇌의 무의식의 작업이라 할 수 있겠다. 미얀 마 난민 아동과 같이 전쟁을 겪으면서 탈출한 아동, 청소년뿐만 아니라 성인들도 재난, 심 한 스트레스나 분노 등의 감정을 뱀과 맹수, 공룡 등을 공격으로 상징화하는 경향이 있다 (장미경, 2017b). 융은(Jang)은 뱀 꿈을 예로 들었다. 위협이 존재할 때 정신의 균형을 잡는 과정은 꿈이나 상징작업에 본능을 나타내는 동물 상징으로 나타나는 경향이 있다. 뱀은 본 능세계의 표상이기도 하지만 뱀 꿈은 때로 의식적 마음의 태도와 본능 사이의 불일치를 나 타내며 갈등의 위협적 측면의 인격화이다. 이는 우리가 "무엇인가 길쭉하고, 구불구불하 며, 매끄럽게 기어가며, 송곳니를 가지고 있고, 날름거리고 둘로 갈라진 혀를 가지고 있는 것"에 대한 위험을 알아차리려는 원형적 기질을 가지고 있기 때문이라고 하였다(Jung, 1984/2008).

“아주 큰 뱀이 사람들을 먹어요. 큰 뱀은 위험하고 무서워요."

- 아동E 1 회기에서 - 


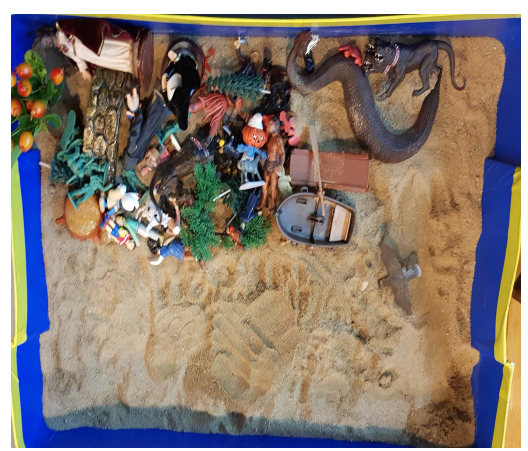

그림 1. 아동 E 1회기 모래장면

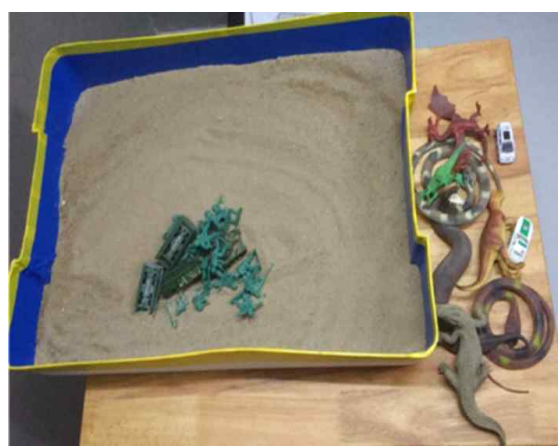

그림 2. 아동 C 2회기 모래장면

아동C의 모래장면에서 팀을 나눈 군인들이 싸우는 장면이 등장한다. 한 팀의 군인은 불 을 무기로 사용하고 다른 한 팀은 총을 무기로 사용하여 싸우는 장면이 인상적이었다. 불 과 총은 같은 성능을 가진 무기라고 할 수 없다. 불은 총을 대항할 수 없다. 모래장면에서 는 강한 무기를 가졌어도 상대방 팀을 이길 수 없는 것을 표현되기도 했다. 그것은 탄압과 무력에 의해 아무것도 하지 못하고 속수무책으로 질 수밖에 없는 자신들의 상태를 보여주 기도 하지만 그럼에도 불구하고 자신들의 삶과 생명을 궁극적으로는 망가뜨리지 못할 것이 라는 마음을 표현한다. 또한 자신의 삶과 터전이 파괴 되어 숲이나 산으로 가게 되고 죽음 을 맞이하게 되는 두려움, 공포 또는 최악의 경우를 상상하면서 무기력한 상태로 두려움을 벗어나려는 표현도 나타났다. 이 아동은 탈출 과정에서 부모의 죽음을 경험하였고 혼자서 정글에서 생활 하는 등 외상 자체에 의해서도 영향을 받았지만 오랫동안 불안정한 삶을 경 험하면서 외롭고 무기력한 감정을 경험하고 있는 것으로 보였다. 극복할 수 없는 감정적 경험은 '지쳐버린 것 같은' '고갈된 것 같은, '분노나 열망으로 소진된' 등으로 표현될 수 있으며 모래장면에서 불, 사막, 재 등으로 상징화 될 수 있다(장미경, 2017a).

"초록 군인은 불을 가지고 있고 회색 군인은 큰 총을 가지고 있어요." "군인들 은 집을 차지하기 위해서 싸워요", “초록 군인들은 싸움에서 지고 나면 산으로 가게 되겠죠." 


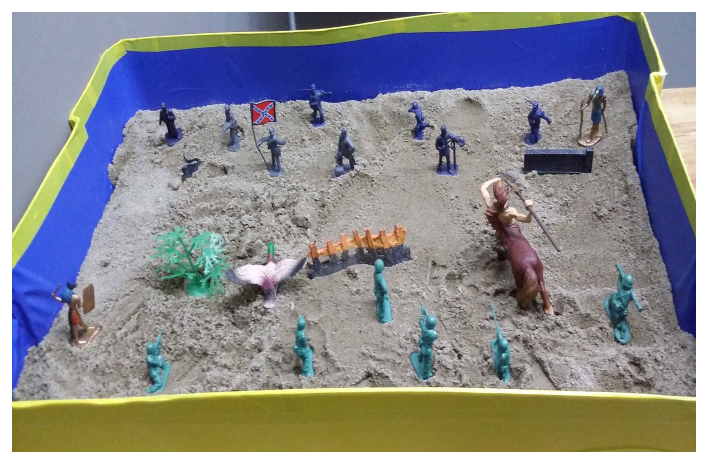

그림 3. 아동 C 1회기 모래장면

\section{2) 보호와 돌봄}

미얀마 난민 아동들이 유일하게 보호와 돌봄을 받을 수 있는 곳은 국제난민학교와 외국 인 선교사에 의해 운영되는 교회이다. 국제난민학교에서 학습과 영양 상태를 살피며 법적 인 문제에 대해서도 도움을 제공한다. 이곳 외의 말레시아 사회로 나갔을 때 경찰에 구금 되거나 벌금을 요구받거나 추방되는 경우도 있어서 이들도 밖으로 나가는 것을 극도로 꺼 린다. 그러나 짐작할 수 있듯이 매우 제한된 생활은 자유를 갈망하게 만든다. 이러한 역할 을 하는 학교와 교회는 모래놀이치료에서 아동들의 보호욕구와 외상, 그리고 보호제공처의 상징으로 자주 등장하였다.

아동들은 모래장면에 요새화 된 영역을 만듦으로서 보호욕구와 외상을 드러내는 장면을 만드는 경향이 있었는데(Grubbs, 1995; Zinni, 1997) 특히 교회와 학교장면이 이런 역할을 하 는 것으로 보였다. 자유롭고 보호적인 공간을 제공하는 것을 중시하는 모래놀이치료는 안 전하게 아동들이 자신의 경험과 감정을 표현하고 공유할 수 있는 테메노스(Temenos) 역할을 했다고 할 수 있다(장미경, 2017a).

아동들 대부분은 모래장면에서 자신들의 기본적인 권리를 보호해주고 돌봄을 주는 피난 처로서 교회, 예수, 성모마리아, 아기예수, 십자가, 목사, 수도자 등을 표현했다. 기독교의 예배당은 상징적으로 세계의 중심이며, 태모(太母)의 보호자적인 측면을 가리키며 보호의 상징이기도 하다(Cooper, 1978). 아동들이 표현한 이런 상징들에 대한 이미지 연상은 따뜻하 고 양육적인 돌봄과 보호하는 헌신적인 이미지였다. 즉 아동들이 주로 사용한 이 상징들은 단순히 현실적인 것만을 나타내는 것은 아니라고 할 수 있다. Jung의 긍정적인 모성원형에 너지는 개인이 심리적으로 위기에 처했을 때 내면에서 여성적인 마술적 권위, 자애로움, 돌 보는 것, 유지하는 것, 성장하고 풍요롭게 영양을 공급하는 제공자, 마술적 변화와 재생의 모체, 도움을 주는 본능이나 충동, 비밀스러운 것을 의미(Jung, 1984/2002)하기 때문에 치유 적이라고 할 수 있다. 
김혜영· 조은진 · 장미경 / 말레이시아 거주 미얀마 친족난민 아동의 모래놀이치료 상징 및 주제연구

아동 $A$ 는 교회 앞에 피겨를 놓은 후 “가족들이 매주 일요일에 모두 교회 앞에 모여서 신에게 기도를 해요"라고 하였다.

- 아동A 1 회기 -

아동 $B$ 는 이 곳은 교회이고 마을이다. 사람들이 신에게 "천국에 가기를 기도한 다. 이 곳은 행복하다.” 라고 기도하는 것이라고 하였다.

- 아동B 1 회기 -

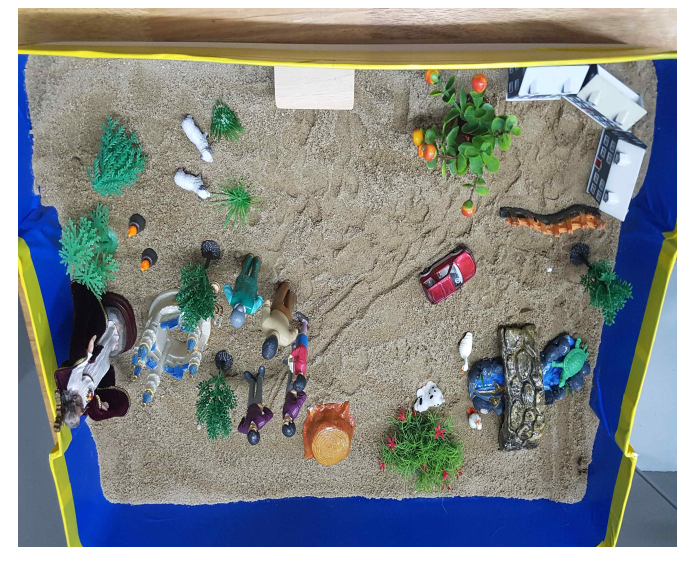

그림 4. 아동 A 1회기 모래장면

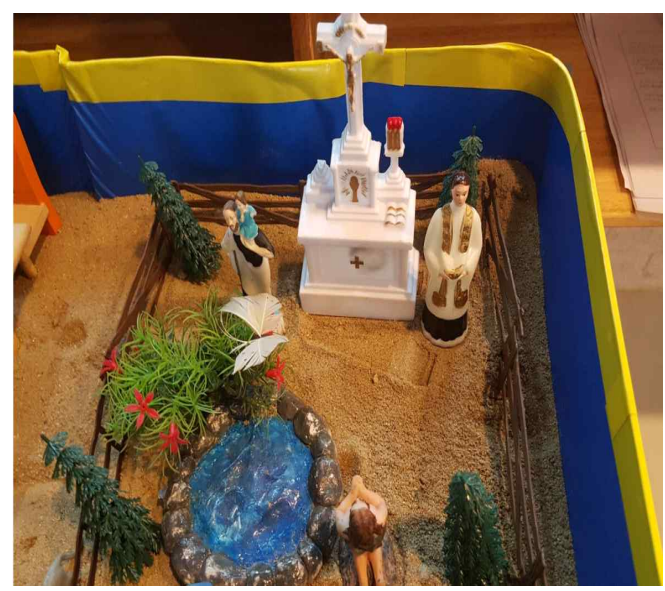

그림 5. 아동 B 1회기 모래장면

\section{3) 신의 존재와 죄책감}

학교와 교회가 제공하는 돌봄과 보호의 측면 외에도 종교의 신은 인간의 정신이 와해되 는 것을 막는 역할을 한다. 이 아동들의 모래장면에서 신은 항상 '그곳'에 있는 존재로 등 장했다. 재난과 고통이 인간을 엄습할 때에 종교 또는 신의 이미지를 떠 올리는 것은 원형 적이다(Jung, 1984/2008: Kim, 2014; 장미경, 2017a). 그 이유는 정신의 균형을 유지하려는 인 간 내면의 시도원리 때문이다(Jung, 1984/2008: Kim, 2014). 이는 모래장면에서 신성한 의식 이나 신성함이 느껴지는 장면들이 이미지로 나타나는 경향이 있으며 이러한 신성함에 이미 지들은 대극사이 즉 고통스런 현실과 이상적인 회복 사이를 연결하는 기능을 가지고 있기 때문에 대극적 갈등을 연결하고 치유하는 기능을 함으로써 증상의 개선을 가져올 뿐만 아 니라 인격의 확장을 가져온다(장미경, 2017a).

어린 시절의 외상이나 정서적, 신체적 학대 등은 성장하면서 죄책감과 자기비난의 경향 이 높게 나타날 수 있다(Salters-Pedneault 외, 2007). 외상경험과 그로 인한 영향은 환경에 지 속적으로 투사된다. 즉 이들의 삶의 환경적 영향이라고 할 수 있는 중요한 사람들의 죽음, 
Journal of Symbols \& Sandplay Therapy, Vol.12 No.1.

질병, 부재, 아동의 부정적 기질, 지지적이지 못한 환경실조 등이 결과적으로 이들에게 내 적-외적 갈등을 일으키고 발달의 자동형성성을 방해하게 되어 자아발달을 저해하고 자아 해체 같은 상태에 빠지게 만든다. 결과적으로 아동은 자기애적 성격, 통합되지 못한 공격성 또는 자신의 존재에 대한 죄책감을 갖게 될 수 있다(장미경, 2017a).

말레이시아에 거주하는 친족 난민아동들은 대부분 기독교적인 배경을 갖고 있고 이들에 게 중요한 환경의 지지제공자도 교회와 관련되어 있다. 이들은 신을 자신들을 지켜주는 존 재로을 표현하기도 했지만 자신의 죄에 대해 벌을 줄 수 있기 때문에 자신들의 죄에 대한 용서를 구해야 하는 존재로 표현하기도 했다. 아동들은 탈출과정에서 자기 자신에게 가장 중요한 가족의 죽음이나 부상을 목격했다. 이들의 죽음이 자신들이 지켜주지 못한 잘못 때 문이라거나 이 모든 혼란스럽고 힘든 과정이 자신들의 잘못 때문이라는 죄책감을 가지고 있었다.

"사람들은 예수님께 (용서를 받기 위해) 성체를 받아먹으려고 줄을 서고 그것 을 받아서 먹고 기도한다".

- 아동E 1 회기

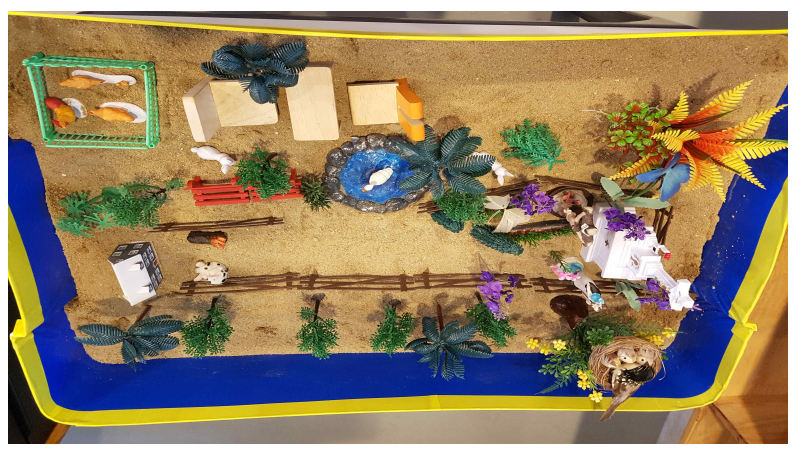

그림 6. 아동 B 2회기 모래장면

“저는 죄인, 용서 기도를 해요."

- 아동B 2회기 -

아동 $E$ 와 $B$ 는 자신들 때문에 이런 일이 생겼기 때문에 용서를 빌어야 한다고 했다.

4) 일상에 대한 회복의 노력

아동들은 모래장면에서 치료기간이 짧았음에도 불구하고 새로운 삶의 회복 하려는 시도 
까지 보여주었다. 아동들은 긴 기다림이 될 수도 있다는 것을 알고 있었으며 삶의 회복을 기대했다. 그 예로, 모래상자에 잃어버린 집 대신 새로운 집을 지으려 했다. 그것은 혼란스 런 환경, 경제적 어려움, 예측할 수 없는 미래의 삶에 대한 불안 등을 극복하기 위해 잘 구 획된 울타리, 정돈된 집, 질서 있는 건축물로 표현 하였다. 질서, 균형감을 주는 이런 이미 지들이 가진 누미노스적 아름다움은 다시 그것을 창조한 만든 아동들에게 영향을 주는 선 순환적 상호작용을 한다(Ammann, 1998). 그 결과로 아동은 불우한 환경에도 불구하고 자아 의 치명적 붕괴 없이 정신 내면의 질서를 유지할 수 있게 된다.

또한 본 연구에 참여한 아동들은 정글에 대한 언급을 많이 했는데 이것은 그들이 살던 곳이 정글이었던 것에 기인하며 다른 한 편 자연의 녹색은 치유의 상징이자 신성성의 상징 이다. 녹색의 힘은 생명을 지탱하는 생명의 근원적인 힘, 초록빛의 생기가 무생물과 생물, 치유력을 지닌 광물, 식물, 동물의 세계에 모두 광범위하게 적용되는 것이다. 기독교 뿐 아 니라 이슬람에서도 녹색은 신성을 나타내는 색으로, 삶 그 자체를 나타내는 색이다(Hidegard of bingen 1983; Ammann, 1998).

"이곳은 섬이에요. 비행기들이 있고 집에는 군인이 살고 있다." “초록색군인 보스와 회색의 보스는 친구이고, 싸우지 않아요.", “이 사람들은 집을 지으려고 정글로 가고 있다. 정글에서 놀면서 싸우는 놀이는 하지 않는다. 초록색 군인들은 정글에 살기를 원한다." 초록색군인들과 회색군인들은 같은 나라이고 같이 살기 를 원한다. "비행기를 타고 미얀마로 날아가고 싶다. 그러면 행복할 것 같다."

- 아동D 5회기 -

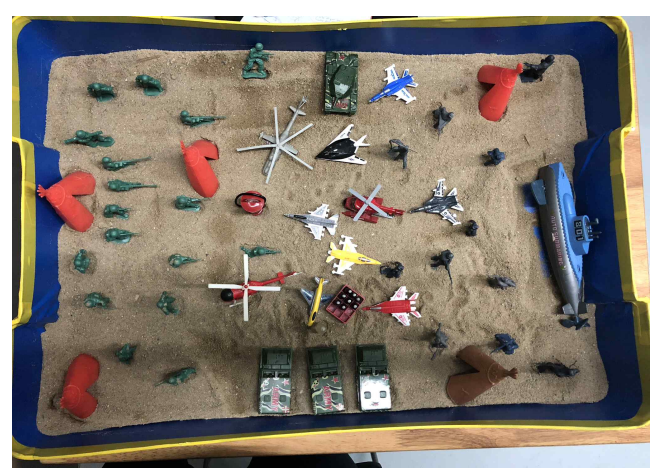

그림 7. 아동 D 5 회기 모래장면 
Journal of Symbols \& Sandplay Therapy, Vol.12 No.1.

"여기 (정글) 아래쪽에 있는 집은 잃어버린 집이고, 크레인 옆에 있는 집은 새 집이에요."

- 아동 $D$ 3회기 -

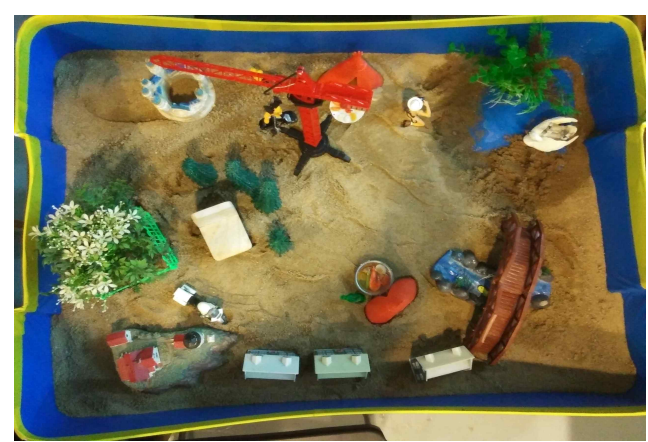

그림 8. 아동 D 3회기 모래장면

5) 평범한 삶에 대한 희망을 버리지 않음

아동들은 미얀마에서 말레이시아로 탈출한 이후 발달단계에 적합한 평범하고 일상적인 것들을 누리지 못하고 있을 뿐 아니라 법적인 이유 등 여러 가지 이유로 말레이시아에서도 매우 제한적인 삶을 살고 있다. 아동들은 모래장면에 현재 평범하게 누려야할 기본적인 권 리와 같은 평범한 삶들, 그럴 수 없는 상황에서 자신이 바라는 희망을 상상 하면서 모래상 자에 표현하였다. 외상 경험 후 일상으로의 회복은 치유과정의 마지막에서 흔히 기대되는 것이지만 과거의 평범한 일상으로 회복할 수 없는 상황에서도 아동들은 일상으로 회복하려 는 장면들을 만들었다. 이것은 현실적 일상에 대한 회복의 기대 또는 바람이기도 하지만 심리적 회복을 의미한다고 판단된다. 이러한 상태는 모래장면에서 극단적인 정신의 원형적 인 요소들은 사라지고, 평범한 사람들의 일상적인 생활 장면이 묘사되는 경향이 있다 (Turner, 2004).

아동A는 피난 과정에서 어머니 사망 후 돌아가시고 아버지와 동생과 살고 있다. 그러나 불행히도 말레이시아에서는 일정한 거주지가 없었다. 5 회기 모래장면의 "아빠는 일하는 중 이다.”, “동생들은 노는 중”이라고 이야기 하고 아기를 침대에 눕히고, 엄마는 음식 먹은 것 을 정리 한 후 청소기를 들고 청소하는 모습, 아빠가 나갔다가 돌아온 후엔 다시 모든 가 족이 식탁에 앉고 엄마는 음식을 차려 식탁에 올려놓는 장면을 모래상자의 표현 한 것은 평범한 일상장면을 표현한 것으로 보여진다.

"아빠는 일하는 중 이다.” “동생들은 노는 중”

- 아동A 5회기 - 


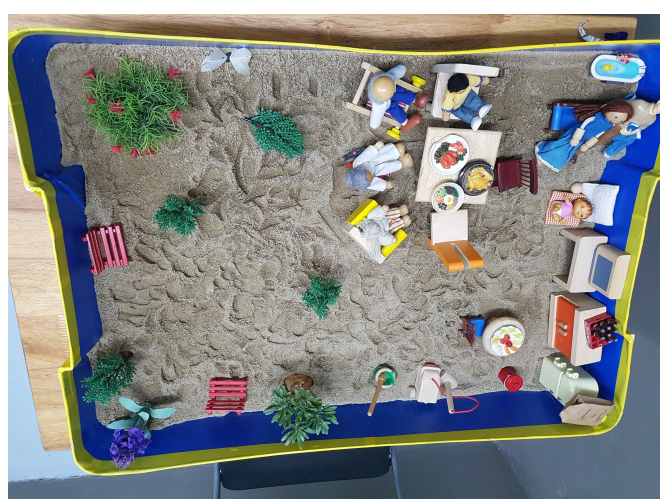

그림 9. 아동 A 5 회기 모래장면

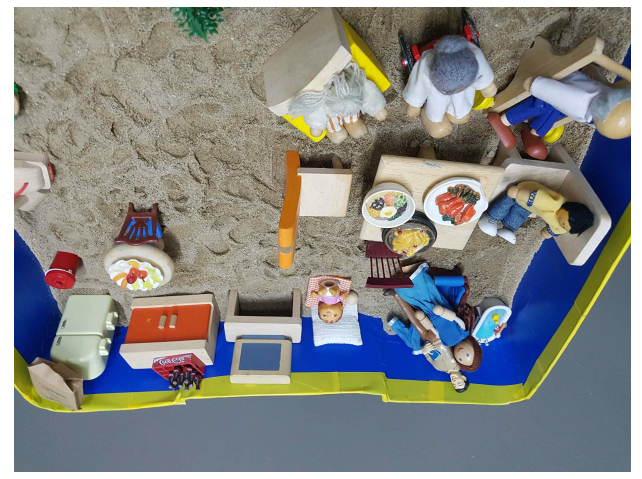

그림 10. 아동A 5회기 모래장면

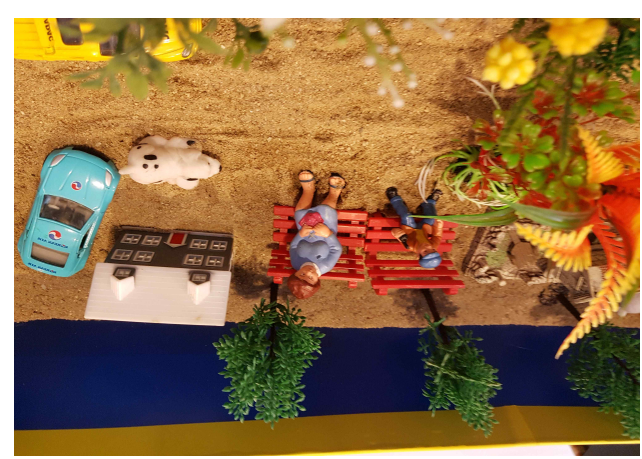

그림 11. 아동 B 4회기 모래장면

\section{$\mathrm{IV}$. 결 론}

본 연구의 목적은 미얀마에서 말레이시아로 탈출하는 과정과 말레이시아에서 재정착 과 정 있는 미얀마 친족 난민아동이 경험한 것에 대한 언어 및 비언어적 표현, 모래놀이장면, 관찰내용, 사용된 피겨 등을 토대로 모래놀이치료과정에서 공통적으로 나타나는 상징 및 주제를 범주화 하여 분석하고자 했다. 연구 참여자는 미얀마를 탈출하여 현재 말레이시아 의 쿠알라룸프르에 거주하고 있으며 유엔이 지원하는 국제난민학교에 다니는 5 명의 미얀마 친족 난민아동이다. 이들은 모두 미얀마에서 말레이시아로 탈출과정에서 학살과 폭력을 직 접 경험하고 가족을 잃어버리거나 죽음을 목격하였다.

이들의 모래놀이치료 과정에서 나타난 상징 및 주제는 사례전체를 통합적으로 분석한 결 과 5 가지의 공통 주제 및 이를 나타내는 상징들을 발견할 수 있었다. 5 가지의 주제는 '두려 
Journal of Symbols \& Sandplay Therapy, Vol.12 No.1.

움/공포 그리고 이에 대한 마음의 저항, ‘보호와 돌봄', '신의 존재와 죄책감' '일상에 대한 회복의 노력, '평범한 삶에 대한 희망을 버리지 않음'의 주제들이었다. 미얀마 친족난민 아 동들은 모래놀이치료에 심리 정서적 고통에 어려움을 모래장면에 표현 하였다. 다양한 외 상을 경험한 미얀마 친족난민 아동은 모래놀이치료 안에는 그들이 경험하고 탈출하는 과정 에서 겪은 혼란스러움이 모래장면에 두드러지게 그리고 반복적으로 나타났으며, 변화한 시 간적인 흐름이 담겨져 있었다. 내면의 고통을 언어화하기 보다는 모래장면에서 더 쉽게 표 현 할 수 있었고, 안전하게 자신을 투사하며 감정을 표출할 수 있었다(Boik \& Goodwin, 2000). 이는 다양한 외상 후 모래장면에서 두드러지게 표현되는 특성으로서 주제가 외상경 험과 유사하게 충동적으로 반복된다는 연구결과(이영애, 2016; 이세화, 장미경, 2018; APA, 2013; Eth, 2001)와 유사한 결과라고 할 수 있다. 미얀마에서 겪었던 폭력이나 탈출에 과정 에서 경험한 폭력과 두려움 뿐 아니라 이에 대에 대해 누르고 있거나 억압되어 있던 감정 은 즉 분노가 무기를 가지고 싸우는 군인, 큰 뱀의 상징을 통해 표현되었다. 이러한 모습은 모든 아동에게서 예외없이 나타났다. 이것은 모래놀이치료에서 전쟁이나 위험을 나타낼 때, 무장한 세력 대신 위험한 동물을 사용하는 경향이 있다는 다른 임상가들의 경험과 일치한 다(Bradway 외, 1997)는 연구결과를 지지한다.

모래놀이치료에서 아동들의 보호욕구와 외상 그리고 보호 제공처로서 아동들은 공통적으 로 모래 상자 안에 권리와 보호해주고 돌봄을 주는 피난처로서는 교회, 예수, 성모마리아, 아기예수, 십자가 등으로 표현함으로써 자신들을 지켜주면서 보호 해 주는 곳으로써 표현 하는 경향이 있었는데 이는 모래놀이치료가 안전하게 아동들이 자신의 종교 문화적 경험과 일치하는 피겨상징을 통해 보호와 돌봄의 욕구를 표현하고 공유할 수 있는 테메노스 (Temenos) 역할을 했다고 할 수 있다(장미경, 2017a).

아동들은 탈출의 과정에서 일어난 가족, 지인, 친지들의 죽음 그리고 현재 삶의 어려움을 자신의 잘못이라는 죄책감을 느꼈으며 신에게 기도하면서 용서받고 싶은 바람을 표현하기 도 했다. 이것은 재난이 인간을 엄습할 때 신을 이미지를 떠올리는 것은 원형적이고 위기 시에 신의 이미지를 떠오르거나 관심을 갖게 되는 것은 정신의 균형을 유지하려는 기능이 라는 언급과 일치한다(Jung, 1984/2008: Kim, 2014). 모래놀이치료 과정은 미얀마 난민 아동 들에게 심리 내면의 대극적이고 갈증적인 갈등을 연결하고 치유하는 것에 도움을 주었다고 할 수 있다(장미경, 2017b).

아동들은 모래놀이치료 회기가 거듭될수록 전쟁이나 공격 장면을 표현하기 보다 점차 평 범하고 안정적인 일상의 삶으로 돌아가고 싶은 마음을 모래상자에 표현하기 시작했다. 처 음에는 표현할 곳이 없었던, 참혹했던 경험에 대한 혼란스런 감정을 표현하기 급급했으나 어느 정도 표현이 이루어지면서 현실에 대한 지각과 결핍에 대해 더 관심을 기울이게 된 것으로 보였다. 이는 전쟁, 자연 재난과 같은 거대한 외상을 경험한 사람들이 모래놀이치료 
와 같은 심리치료를 통하거나 내면의 자연스런 회복기제에 의해 시간의 흐름과 함께 어느 정도 안정감을 회복하게 되면서 일상으로 돌아가고자 하는 희망을 보이기 시작한다는 연구 결과와 유사한 과정을 보였다고 할 수 있다.(이세화, 장미경, 2020) 이러한 연구 결과와 같 이 실제로 위험과 손상으로부터 보호 및 보살핌에 대한 옥구 혼돈에서 삶의 질서를 회복하 고자 하는 것 일상에 대한 삶을 희망을 버리지 않음을 모래상자에 표현한 이것은 현실적 일상에 대한 회복의 기대 또는 바람이기도 하지만 심리적 회복을 의미한다고 판단된다. 이 러한 상태는 모래장면에서 극단적인 정신의 원형적인 요소들은 사라지고, 평범한 사람들의 일상적인 생활 장면이 묘사되는 경향이 있다는 것을 다시 한 번 이야기 할 수 있다(Turner, 2004).

모래놀이치료 개입을 통해 이루어진 미얀마 친족 난민아동에 대한 개입이 위에서 언급한 바와 같은 효과성이 있었다. 특히 조국이 아닌 말레이시아라는 외국으로 피난하였고 영어 를 사용하는 국제학교에 다니기 때문에 여러 가지 낮선 언어에 노출되어 있는 아동들에게 언어에 초점을 맞추기 보다는 상징과 놀이를 사용하는 모래놀이치료 접근은 이들이 외상적 경험과 그로인한 감정을 표현하기에 적합하다고 할 수 있다. 그러나 본 연구의 기간이 4 주 라는 점을 고려할 때문에 효과성 측면에서 제한적이며 미얀마 친족 난민아동 가지고 있는 복잡한 환경 및 상황의 어려움과 심리적 특성을 모두 이해할 수 있는 기회가 되었다고 결 론내리기는 어렵다. 그러나 짧은 개입기간과 언어적 어려움에도 불구하고 비교적 긍정적인 효과를 보인 것은 모든 아동들과 마찬가지로 이 아동들이 가지고 있는 본성적, 원형적 치 유력 그리고 이들의 경험의 참혹함 그리고 처해 있는 불안정한 상황이 짧은 기간의 개입에 강하게 반응할 수 있게 한 것으로 보인다. 이러한 논의점들은 앞으로 난민아동들의 사회 문화적 특수성과 다양한 심리 - 정서적 문제들을 고려한 심리치료적 접근이 물리적, 경제적 원조 및 법적 지위확보와 함께 통합적으로 주어져야할 필요를 의미한다. 또한 난민이라는 특수성으로 인해 심리치료적 지원이 단기로 이루어져야함을 감안할 때 모래놀이치료가 단 기 그리고 소집단으로 제공될 때 효과성을 가질 수 있음을 시사한다고 할 수 있다. 더 나

아가 피난 직후의 위기개입이 이루어져야 함도 시사한다고 할 수 있다. 위기개입 지원은 이후의 발생할 수 있는 심리적 외상으로 인한 정신적 질병의 발병, 가정의 파괴, 새로운 환 경에의 부적응 등의 심각한 문제발생을 예장할 수 있게 할 것이다.

\section{참고문헌}

송효진, 김소영, 이인선, 한지영 (2018). 한국에서의 난민여성의 삶과 인권. 이화젠더법학.

10(3), 149-189. Doi: https//doi.org/10.22791/ewhagl.2018.10.3.005 
Journal of Symbols \& Sandplay Therapy, Vol.12 No.1.

연합뉴스 (2018년 4월 29일). 말레이 “송환 대상 미얀마인 1천200명은 난민 아닌 불법체류”.

2021년 3월 20일 검색, https://www.yna.co.kr/view/AKR20180429022800104

연합뉴스 (2021년 2월 16일). 말레이 “송환 대상 미얀마인 1천200명은 난민 아닌 불법체류".

2021년 3월 20일 검색, https://www.yna.co.kr/view/AKR20210216080200104

유엔난민기구 (2010). 말레이시아 난민들이 운영하는 학교 어린이들에게 교육기회 제공.

2020년 12월 2일 검색 https:// www.unhcr.or.kr

오수성, 신현균, 김상훈 (2009). 외상 후 스트레스 장애 워크북. 서울: 학지사.

이부연, 장미경 (2015). 북한이탈청소년과 남한청소년의 모래놀이치료에서의 표현 상태 비

교. 상징과 모래놀이치료, 6(2), 31-45

이영애 (2016). 놀이치료 과정에서 학대받은 아동의 외상 후 놀이특성 분석. 한국놀이치료학

회지, 19(2), 335-362. DOI :https//doi.org/10.17641/KAPT.19.4.4

이세화, 장미경 (2020). The Effect of Group Sandplay Therapy on psychological Health and

Resilience of Adolescent Survivors of Nepal Earthquake. 상징과 모래놀이치료, 11(2), 45-78.

DOI: http://doi.org/10.12964/jsst.20007

이세화, 장미경 (2018). 말레이시아 거주 로힝야족 난민 아동의 집단모래놀이치료 주제 및

상징연구. 상징과 모래놀이치료, 9(1), 66-67. DOI: https://doi.org/10.12964/jsst.1800

장미경 (2017a). 분석심리학적 모래놀이치료. 서울: 학지사.

장미경 (2017b). Archetypal symbolism in the recovery process from natural disaster: sandplay

therapy of earthquake adolescent survivors. 상징과 모래놀이치료, 8(2), 1-21.

장복희 (2017). 동아시아 난민법 개정을 통한 사정변경 없는 난민재신청 제한의 필요성. 외

법논법, 17(6), 417-445.

장준영 (2012). 미얀마 외교정책의 변화와 주요 국가의 관계. 서울: 대회정책 연구.

최남희 (2006). 재난 피해자 사후 지원: 재난 피해자의 사회 복귀. 한국위기관리논집, 2(2), $1-18$.

허춘중 (2017). 미얀마의 난민들, 그리고 선교적 돌봄. 기독교사상, 708, 47-57.

Alayarian, A. (2007). Resilience, Suffering, and Creativity - The work of the Refuge (2011).(역). 난민치료

센터 상담중심의 트라우마 회복탄력성과 상담실제. 서울: 시그마프레스

DOI: $10.1080 / 13642530701571682$

Albert, E. (2017). Council on Foreign Relations. Retrieved from the Rohingya Migrant Crisis.

Available online: http://www.cfr.org/burmamyanmar/rohingya-migrant-crisis/p36651(accessed on

September 2018) Bangladesh Fact sheet (2016). UNHCR: Geneva, Switzerland.

American Psychiatric Association (2000). Diagnostic and statistical manual of menual of mental disorders

(4th test revision American Psychiatric Association). DOI: https://doi.org/10.1192/bjp.179.1.85-a 
Ammann, R. (1998). Healing and transformation in sandplay: Creative processes become visible. Chicago: Open Court.

Bartholomew, T., Gundel., \& Kantamneni, N. (2015). A dream best forgotten: The phenomenology of Koren Refugees' pre-resettlement stressors. Counseling Psychologist, 43(8), 1114-1134. DOI: https://doi.org/10.1177/0011000015606221

Beman, H. (2011). Children and War: Current Understandings and Future Directions. Public Health Nursing 18, 243-252. DOI: https://doi.org/10.1046/j.1525-1446.2001.00243.x

Bengi-Arslan, L., VerhulstF. C., Ende. J. Van der., \& Erol., N. (1997). Understanding childhood(prblem) behaviors and competencies in Turkish immigr ant, Turkish and Dutch childrcen. Socialpsychiatry \& Psychiatric Epidemiology, 32, 477-484. DOI: https://doi.org/10.1007/BF00789143

Boik, B. L., \& Goodwin, E. A(2000). Sandplay: A step-by-step manual for psychotherapies of diverse orientations. New York: W. W. Norton \& Company.

DOI: https://doi.org/10.1016/S0197-4556(01)00105-8

Bradway, K. \& McCoard, B (1997). Sandplay Silent Workshop of the psyche. NY: Routledge. DOI: https://doi.org/10.4324/9780203977576

Chemtob, C., Nomura, Y., \& Abramovitz, R. (2008). Impact of conjoined exposure to the World Trade Center attacks and to other traumatic events on the behavioral problems of preschool children. Archive of Pediatric and Adolescent Medicine, 162(2), 126-133. DOI:

https://doi.org/10.1001/archpediatrics.2007.36

Chemtob, C. M., Nomura, Y., Rajendran, K., Yehuda, R., Schwartz, D., \& Abramovitz, R. (2010). Impact of maternal posttraumatic stress disorder and depression following exposure to the September 11 attacks on preschool children's behavior. Child Development, 81, 1129-1141. DOI: https://doi.org/10.1111/j.1467-8624.2010.01458.x

Creswell, J. (2007). Qualitative inquiry and research design: Choosing among five tradition (2ed.). Thousand Oaks, CA: Sage.

Cook A., \& Spinazzola, J. (2005). Complex trauma in children and adolescents. Psychiatric Annals, 35(5), 390-398

Cooper, J. C. (1978). An Illustrated encyclopaedia of traditional symbols. NY: Thames \& Hudson. 이윤기 (2012). (역). 그림으로 보는 세계문화상징사전. 서울: 까치글방.

Davies, M., \& Webb, E. (2000). Promoting the Psychological Well-Being of Refugee Children. Clinical Child Psychology and Psychiatry, 5(4), 541-554.

DOI: https://doi.org/10.1177\%2F1359104500005004008

Deeba, F., Rapee, R. M., \& Prvan T. (2014). Psychometric proprties of the children's Revised Impact 
Journal of Symbols \& Sandplay Therapy, Vol.12 No.1.

of Events Scale (CRIES) with Bangladesh children and adolescents. Peer J, 2:e536. DOI: https://doi.org/10.7717/peerj.536

Deeba, F., \& Rapee, M. (2015). revalence of traumatic events and risk for psychological symptoms among community and at-risk children and adolescents from Bangladesh. Child and Adolescent Mental Health, 204), 218-224. DOI: https://doi.org/10.1111/camh.12093

Ehntholt, K. A, Trickey, D., Harris, H. J., Chamvers, H, Scott, M, \& Yule, W. (2018). Mental health of unaccompanied asylum-seeking adolescents previously held in British Detention Centres. Clinical Child Psychiatry, 23(2), 238-257. DOI: https://doi.org/10.1177\%2F1359104518758839

Eth, S (2001). Introduction: Childhood trauma in perspective. In S Eth (ed.), PTSD in Children and adolescents Washihgton, DC: American Psychiatric Publishing.

DOI: https://doi.org/10.1023/A:1009564724720

Friedman, H. S., \& Mithell, R. R. (2008). Supervison of Sandplay Therapy. England: Psychology Press. 장미경, 이미애, 이상희, 채경선, 홍은주 (2011). (역). 모래놀이치료 슈퍼비젼. 서울: 한국임 상모래놀이치료학회.

Gil, E. (2006). Helping abused and traumatized children: Integrating directive and nondirective approaches. New York: Guilford Press.

Grantham-McGregor, S., Cheung, Y. B., Cueto, S., Glewwe, P., Richter, L., \& Strupp, B. (2007). Developmental potential in the first 5 years for children in developing countries. The Lancet, 369, 60-70. DOI:https://doi.org/10.1016/S0140-6736(07)60032-4

Gabried Uhlein (1983). Meditations with Hildegard of Bingen. New Mexico: Bear \& company. p.77

Jung, C. G. (1984/2008). 인간의 상과 신의 상(Menschenbild und Gottesbild). 한국융연구원 C. G. 융 저작 번역서 2권. (한국융연구원 C. G. 융저작 번역위원회 역). 서울: 솔출판사.

Jung, C. G. (1984/2002). 원형과 무의식(Archetyp und Unbewusstes). 한국융연구원 C. G. 융 저작 번 역서 2권. (한국융연구원 C. G. 융 저작 번역위원회 역). 서울: 솔출판사.

Kalff, D. M. (1980). Sandplay: A psychotherapeutic approach to the psyche. Boston, IL.: Sigo Press.

Kalff, D. M. (2003). Sandplay: A psychotherapeutic Approach to the psyche. cloverdale, CA: Temenos Press(original work published in 1980).

Karlsen, S., \& Nazroo, J. Y. (2002). Relation between racial discrimination, social class, and health among ethnic minority groups. American Journal of Public Health, 92, 624-631. DOI: https://doi.org/10.2105/AJPH.92.4.624

Kaur (2007). Refugees and refugee policy in Malaysia. UNEAC Asia Papers, 18, 77-90.

Kawai, T. (2015). Big stories and small stories in the psychology relief work after the earthquake disaster: Life and death. In Huskinson, L. \& Stein, M., Analytical psychology in a changing world: 
The search for Self, identity and community. NY: Routledge. DOI:

http://library.oapen.org/handle/20.500.12657/22277

Kim, S. (2014). Psychology and religion: Focused on the thought of C. G. Jung. Theology and Praxis, 34, 285-318.

Kimayer, L. J. Narasia, L., Munoz, M Rashid. M, Ryder, A. G., Guzder, j., Hassan, G., Rousseau, C., \& Pottie, k. (2011). "Common Mental Health Problems in Immigrants and Refugee: General Approach in Primary Care." Canadicn Medical Association Journal, 83(12), 959-967. DOI:

https://doi.org/10.1503/cmaj.090292

Lacroix, L., Rousseau, C., Gauthier M-F., Singh, A., Giguere, N., \& Lemzoudi, Y. (2007). Immigrant and refugee preschoolers' sandplay representation the tsunami. Arts in Psychotherapy, 34, 99-113. DOI: https://doi.org/10.1016/j.aip.2006.09.006

Malchiod. C. A. \& Crenshaw. D. A(2013). Creative Arts play Therapy for Attachment problems. 김유진, 류진아, 신현정, 윤미원, 장미경, 최명선, 홍은주 (2019). (역). 애착해결을 위한 창의적 예술 치료와 놀이치료. 서울: 학지사.

Malchiodi, C. (2003). Using creative activities as intervention for grieving children in preschool triads. Developmental Psychology, 20, 807-814.

Malchiodi, C. A. (1997). Breaking the silence: Art therapy with children from violent homes (2nd ed.). New York: Brunner-Routledge.

Malchiodi, C. A. (Ed.). (2005). Expressive therapies. New York: Guilford press.

Malchiodi, C. A. (Ed.). (2008). Creative interventions with traumatized children. New York: Guilford press.

Mohamed Ashraf Alam (2015). Historical Background of Arakan. Available online: http://sayedarakani48.webs.com.arakanhistory.htm (accessed 4, Nov 2020).

Reynolds, C. R., \& Kamphaus, R. W. (2004). Behavior assessment for children (BASC-2). Circle Pines, MN: American Guidance Service. DOI: https://doi.org/10.1177/15345084070320020301

Rowland, S. (1999). C. G. Jung and literary theory. In C. G. Jung and Literary Theory, 188-201. London: Palgrave Macmillan.

Rutter M. L. (1999). Psychosocial adversity and child psychopathology. British Journal of Psychiatry, 174, 480-493. DOI: http://doi.org/10.1192/bjp.174.6.480

Salters-Pedneault, K., Gentes, E., \& Roemer, L. (2007). The role of fear of emotion in distress, arousal, and cognitive interference following an emotional stimulus. Cognitive Behaviour Therapy, 36, 12-22. DOI: https://doi/10.1080/1650607060087428

Sandhu, D. S., \& Asrabadi, B. R. (1994). Development of an acculturative stress scale for 
Journal of Symbols \& Sandplay Therapy, Vol.12 No.1.

international students: Preliminary findings. Psychological Reports, 75(1), 435-448. DOI:

https://doi.org/10.2466/pr0.1994.75.1.435

Scheeringa, M. S., \& Zeanah, C. H. (2008). Reconsideration of harm's way: Onsets and comorbidity patterns of disorders in preschool children and their caregivers following hurricane Katrina. Journal of Clinical Child \& Adolescent Psychology, 37(3), 508-518.

DOI: https://doi.org/10.1080/15374410802148178

Seitz, H. (2017). 10 Facts about Refugees in Malaysia. Available online https://borgenproject.org/about-refugees-in-malaysia(accessed 5, Nov 2020).

Stake, R. (1995). The Art of Case Study Research.. Thousand Oaks. CA: Sage.

Steele, W. (2006). When cognitive interventions fail with children of trauma: Memory, learning, and trauma intervention. Available online: http://www.tlcinstitue.org/cognitiveinterventions.html

Turner, B. A. (2005). The handbook of sandplay therapy. Los Angeles, CA: Temonos Press.

UNHCR (2015) UNHCR Subregional Operations Profile - South-East Asia - Malaysia. Available online: http://www.unhcr.org/cgibin/texis/vtx/page?page $=49$ e4884c6\&submit $=\mathrm{GO}$ (accessed 28, Oct 2020)

UNHCR (2017). Over 168,000 Rohingya likely fled Myanmar since 2012. Available online: http://www.unhcr.org/news/latest/2017/5/590990ff4/168000-rohingya-likely-fled-myanmar-since-2012unhcr-report.html?query= Rohingya(accessed 29, Oct 2020).

Werner E. E., Smith R. S. (1982). Vulnerable but invincible: A longitudinal study of resilient children and youth. New York: McGraw Hill. DOI: https://doi.org/10.1515/9783110860153-011

투고일 : 2021. 03. 30

수정인 : 2021. 06. 21 게재확정일 : 2021. 07. 01 